\title{
A Concise Total Synthesis of dl-Histrionicotoxin.
}

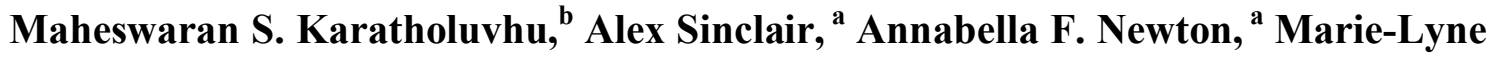 \\ Alcaraz, ${ }^{\text {c }}$ Robert A. Stockman ${ }^{\mathrm{a}, *}$ and Philip L. Fuchs ${ }^{\mathrm{b}, *}$
}

${ }^{\text {a }}$ School of Chemical Sciences and Pharmacy, University of East Anglia, Norwich,

\author{
NR4 7TJ, UK \\ ${ }^{\mathrm{b}}$ Department of Chemistry, 560 Oval Drive, Purdue University, West Lafayette, IN 47907 \\ ${ }^{\mathrm{c}}$ AstraZeneca, Bakewell Road, Loughborough, Leics LE11 5RH, UK
}

\section{Supporting Information}

For syntheses of the histrionicotoxins not covered by reviews, see:

1. Diedrichs, N.; Krelaus, R.; Gedrath, I.; Westermann, B, Can. J. Chem., 2002, 80, 686.

2. Davison, E. C.; Fox, M. E.; Holmes, A. B.; Roughley, S. D.; Smith, C. J.; Williams, G. M.; Davies, J. E.; Raithby, P. R.; Adams, J. P.; Forbes, I. T.; Press, N. J.; Thompson, M. J. J. Chem. Soc., Perkin Trans. 1, 2002, 1494.

3. Luzzio, F. A.; Fitch, R. W. J. Org. Chem. 1999, 64, 5485.

4. Tanner, D.; Hagberg, L.; Poulsen, A. Tetrahedron 1999, 55, 1427.

5. Comins, D. L.; Zhang, Y.; Zheng, X. Chem. Commun. 1998, 2509.

6. Tanner, D.; Hagberg, L. Tetrahedron 1998, 54, 7907.

7. Kim, D.; Hong, S. W.; Park, C. W. Chem. Commun. 1997, 2263.

8. Compain, P.; Gore, J.; Vatele, J. M. Tetrahedron Lett. 1995, 36, 4063.

9. Maezaki, N.; Fukuyama, H.; Yagi, S.; Tanaka, T.; Iwata, C. J. Chem. Soc., Chem. Commun. 1994, 1835.

10. Zhu, J.; Royer, J.; Quirion, J-C.; Husson, H-P. Tetrahedron Lett. 1991, 32, 2485.

11. Winkler, J. D.; Hershberger, P. M. J. Am. Chem. Soc. 1989, 111, 4852.

12. Wardrop, D. J.; Zhang, W. M.; Landrie, C. L. Tetrahedron Lett. 2004, 45, 4229

13. Kim, S.; Ko H.; Lee, T.; Kim, D. J. Org. Chem. 2005, 70, 5756.

14. Provoost, O. Y.; Hedley, S. J.; Hazlewood, A. J.; Harrity, J. P. A. Tetrahedron Lett. 2006, 47, 331.

For synthetic approaches see:

15. Malassene, R.; Vanquelef, E.; Toupet, L.; Hurvois, J. P.; Moinet, C. Org. Biol. Chem. 2003, 1, 547.

16. Comins, D. L.; Zheng, X. J. Chem. Soc., Chem. Commun. 1994, 2681.

17. Parsons, P. J.; Angell, R.; Naylor, A.; Tyrell, E. J. Chem. Soc., Chem. Commun. 1993, 366.

18. Thompson, C. M. Heterocycles 1992, 34, 979.

19. Venit, J. J.; DiPierro, M.; Magnus, P. J. Org. Chem. 1989, 54, 4298.

20. Wybrow, R. A. J.; Edwards, A. S.; Stevenson, N. G.; Adams, H.; Johnstone, C.; Harrity, J. P. A. Tetrahedron 2004, 60, 8869.

21. Horsley, H. T.; Holmes, A. B.; Davies, J. E.; Goodman, J. M.; Silva, M. A.; Pascu, S. I.; Collins, I. Org. Biomol. Chem. 2004, 2, 1258.

22. Bera, S. Heterocycles 2005, 65, 2901. 
General Considerations: All solvents were purified prior to use, except where indicated. Tetrahydrofuran and diethyl ether were dried by distillation from sodium benzophenone ketyl. Toluene was distilled from calcium hydride. Reagents were purchased and directly used, except where indicated. Molecular sieves were activated by heating overnight at $150-170^{\circ} \mathrm{C}$ oven.

All reactions were conducted under a nitrogen atmosphere using oven dried glassware which was fitted with rubber septa. Nitrogen was dried by passing through Drierite ${ }^{\mathrm{TM}}$. Solvents and liquid reagents were transferred via syringes unless otherwise indicated. Reactions were monitored by thin layer chromatography (TLC) with glass-backed silica gel $60 \mathrm{~F} 254$ plates (EM reagents, 0.25mm). Compounds were first visualized with a UV lamp $(254 \mathrm{~nm})$, then stained in p-anisaldehyde solution $(1350 \mathrm{~L}$ absolute ethanol, $50 \mathrm{~mL}$ of concentrated sulfuric acid, $15 \mathrm{~mL}$ of glacial acetic acid and $37 \mathrm{~mL}$ of p-anisaldehyde) and permanganate solution $\left(1.5 \mathrm{~g} \mathrm{KMnO}_{4}, 10 \mathrm{~g} \mathrm{~K}_{2} \mathrm{CO}_{3}, 2.5 \mathrm{~mL} 5 \% \mathrm{NaOH}\right.$ in $150 \mathrm{~mL} \mathrm{H}_{2} \mathrm{O}$ ). Reactions were worked up by adding one equal volume of saturated ammonium chloride solution or $5 \%$ hydrochloride acid solution in water, followed by three extractions with an equal volume of the stated organic solvents for each extraction, except otherwise noted. All organic extracts were dried over anhydrous sodium sulfate or magnesium sulfate and all organic solvents were removed by a rotary evaporator under reduced pressure. Unless otherwise indicated, products were purified by flash column chromatography on silica gel of 230-400 mesh by gradual elution using ethylacetate in hexane or hexane as the case may be and the yields reported are isolated yields.

\section{Physical Methods (Purdue)}

Identification of E,Z olefinic compounds was done by ${ }^{1} \mathrm{H}$ and ${ }^{13} \mathrm{C}$ NMR experiments and tabulated NMR data is attached for review. ${ }^{1} \mathrm{H}$ and ${ }^{13} \mathrm{C}$ spectrum assignments were made by decoupling experiments.

${ }^{1} \mathrm{H}$ and ${ }^{13} \mathrm{C}$ NMR spectra were recorded with $\delta$ values on a Varian INOVA-300 spectrometer. The proton signal of residual, non-deuterated solvent was used as an 
internal reference $\left(\delta 7.24\right.$ for $\mathrm{CHCl}_{3}$,). For ${ }^{13} \mathrm{C}$ spectra, the chemical shifts are reported relative to $\delta 77.0$ for $\mathrm{CDCl}_{3}$. Mass spectra were recorded at the Purdue University campus-wide mass spectrometry facility.

\section{Physical Methods (UEA)}

${ }^{1} \mathrm{H}$ NMR spectra were recorded at either 300 or $400 \mathrm{MHz}$ while ${ }^{13} \mathrm{C}$ NMR spectra were recorded at either 75 or $100 \mathrm{MHz}$ on either a Varian Gemini 300 spectrometer or a Varian 400 Lambda spectrometer respectively. All NMR spectra were carried out in solution using deuteriated chloroform $\left(\mathrm{CDCl}_{3}\right)$ as the solvent, unless otherwise stated. Signals are quoted in ppm as $\delta$ downfield from the tetramethylsilane internal standard $(\delta=0.00)$. The nucleus and operating frequency are indicated for each set of data and coupling constant $J$ values given in Hertz.

Infrared spectra were recorded on a Perkin-Elmer 1720X FT-IR spectrophotometer as thin films on a $\mathrm{KBr}$ or $\mathrm{NaCl}$ plate.

Low resolution mass spectra EI (low resolution electron impact); ES (low resolution electrospray; CI (chemical ionization; HRMS (high resolution mass spectrometry) were obtained via the EPSRC National Mass Spectroscopy Service Centre at the University of Wales, Swansea.

TLC analysis was carried out on Fluka glass backed silica gel $60 \mathrm{~F}_{254}$ coated plates, or Merck aluminium backed aluminium oxide $60 \mathrm{~F}_{254}$ coated plates and were visualised by one or a combination of the following methods: (a) viewing under UV at 254nm; (b) exposure to iodine vapour, (c) exposure to a aqueous potassium permanganate solution, containing $3 \mathrm{~g}$ of $\mathrm{KMnO}_{4}, 20 \mathrm{~g}$ of $\mathrm{K}_{2} \mathrm{CO}_{3}, 5 \mathrm{~mL}$ of $2 \mathrm{M}$ aqueous $\mathrm{NaOH}$ and $300 \mathrm{~mL}$ of $\mathrm{H}_{2} \mathrm{O}$; (d) exposure to an $8 \%$ ethanolic phosphomolybdic acid solution; (e) exposure to an ethanolic vanillin solution, containing $6 \mathrm{~g}$ of 4-hydroxy-3-methoxy-benzaldehyde, 250 $\mathrm{mL}$ of EtOH and $2.5 \mathrm{~mL}$ of $12 \mathrm{M}$ aqueous $\mathrm{H}_{2} \mathrm{SO}_{4}$. 
Characterization Check List

\begin{tabular}{|c|c|c|c|c|c|}
\hline$\#$ & Compound & 夏 H NMR & ${ }^{13} \mathrm{C}$ NMR & MS & HRMS \\
\hline & & $\mathrm{O}$ & $\mathrm{O}$ & $\mathrm{O}$ & $\mathrm{O}$ \\
\hline 7 & & $\mathrm{O}$ & $\mathrm{O}$ & $\mathrm{O}$ & $\mathrm{O}$ \\
\hline 8 & & $\mathrm{O}$ & $\mathrm{O}$ & $\mathrm{O}$ & $\mathrm{O}$ \\
\hline 9 & & $\mathrm{O}$ & $\mathrm{O}$ & & \\
\hline 11 & & $\mathrm{O}$ & $\mathrm{O}$ & $\mathrm{O}$ & $\mathrm{O}$ \\
\hline 14 & & $\mathrm{O}$ & $\mathrm{O}$ & $\mathrm{O}$ & $\mathrm{O}$ \\
\hline 15 & & $\mathrm{O}$ & $\mathrm{O}$ & $\mathrm{O}$ & $\mathrm{O}$ \\
\hline
\end{tabular}




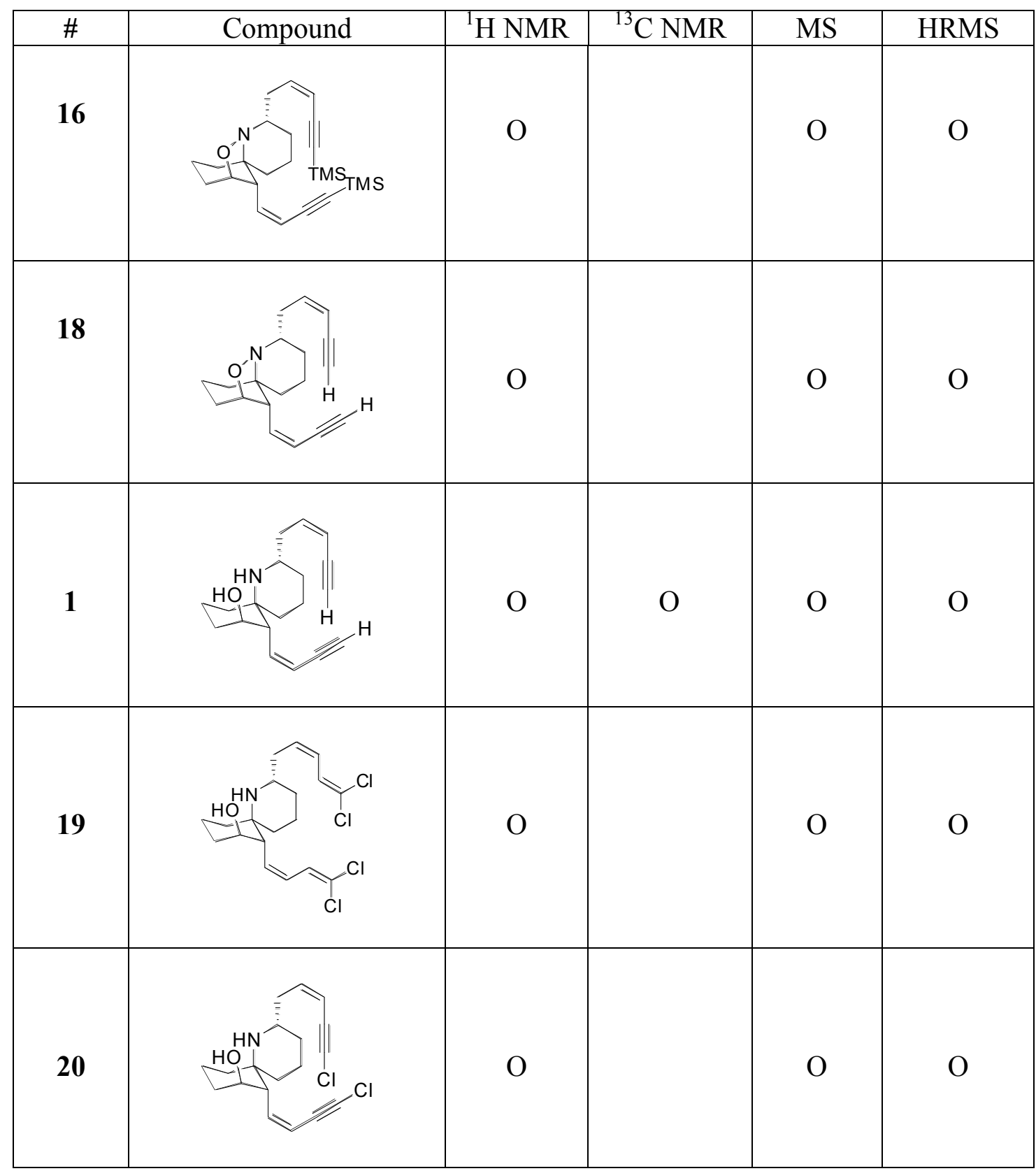




\section{TOTAL SYNTHESIS OF ( $( \pm)$ HTX 1}

\section{Preparation of keto-dinitrile 4}

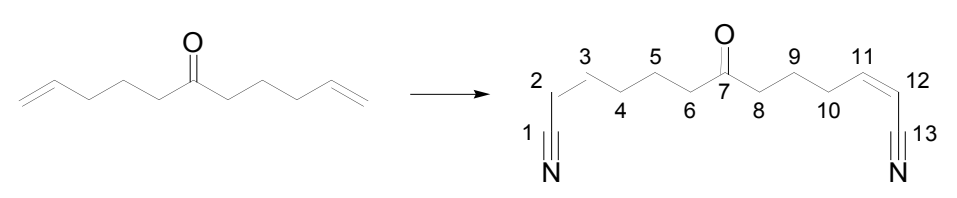

Microwave conditions: All microwave irradiations were carried out with a Biotage Initiator 2.0 Microwave Reactor (400 W). To a solution of undeca-1,10-dien-6-one (1.203 mmol, $200 \mathrm{mg}, 1 \mathrm{eq})$ in dicholomethane $(20 \mathrm{~mL})$ under $\mathrm{Ar}$, was added acrylonitrile ( $3.609 \mathrm{mmol}, 191 \mathrm{mg}, 3 \mathrm{eq})$ and catalyst $5(0.120 \mathrm{mmol}, 70 \mathrm{mg}, 10 \mathrm{~mol} \%)$. The vial was sealed and irradiated in a microwave reactor for 1 hour at $140{ }^{\circ} \mathrm{C}$ (pressure $12 \mathrm{bar})$. Another portion of catalyst $(0.060 \mathrm{mmol}, 38 \mathrm{mg}, 5 \mathrm{~mol} \%)$ was added, and the vial irradiated for $4 \mathrm{hrs}$ at $120{ }^{\circ} \mathrm{C}$ (9 bar), after which time a further portion of catalyst ( $0.060 \mathrm{mmol}, 38 \mathrm{mg}, 5 \mathrm{~mol} \%$ ) was added, and the sample was further irradiated for $1 \mathrm{hr}$ at $140{ }^{\circ} \mathrm{C}$ (12 bar) Another portion of acrylonitrile (3.609 mmol, $\left.191 \mathrm{mg}, 3 \mathrm{eq}\right)$ was added, and the sample was irradiated for $2 \mathrm{hrs}$ at $140{ }^{\circ} \mathrm{C}(11 \mathrm{bar})$ after which time the solvent was removed, and the residue was redissolved in acrylonitrile. The solution was stirred for 10 mins, and then concentrated. Purification by column chromatography (eluting with 3:1 hexanes/ethyl acetate) yielded the product as a clear yellow oil (162 mg, $0.75 \mathrm{mmol}, 62 \%)$

Thermal conditions: To a solution of undeca-1,10-dien-6-one $(1.20 \mathrm{mmol}, 200 \mathrm{mg}, 1$ eq) in tetrahydrofuran $(20 \mathrm{~mL})$ under Ar, was added acrylonitrile $(1.80 \mathrm{mmol}, 96 \mathrm{mg}, 3$ eq) and catalyst $5(0.060 \mathrm{mmol}, 38 \mathrm{mg}, 5 \mathrm{~mol} \%)$. The solution was heated to $\sim 70{ }^{\circ} \mathrm{C}$ and stirred for 2 weeks, adding further portions of catalyst at 2 day intervals. The solution was concentrated, redissolved in neat acrylonitrile, and concentrated again. The darkbrown residue was washed repeatedly with ethyl acetate, and the solvent removed. Purification by column chromatography (eluting with 2:1 PE/EA) yielded the product as a clear oil (146 mg, $0.68 \mathrm{mmol}, 56 \%)$ 7-Oxo-trideca-2,11-dienedinitrile (4) IR (NaCl, thin film) $/ \mathrm{cm}^{-1} 2217.92(\mathrm{CN}), 1705.83(\mathrm{C}=\mathrm{O})$; 
1H NMR (400 MHz; $\left.\mathrm{CDCl}_{3}\right) \delta 6.40(1.83 \mathrm{H}, \mathrm{dt}, J 10.8$ and 7.6), $5.29(2 \mathrm{H}, \mathrm{d}, J 11.6), 2.39$

$(8 \mathrm{H}, \mathrm{m}), 1.70(4 \mathrm{H}, \mathrm{m})$

13C NMR (100 MHz, $\left.\mathrm{CDCl}_{3}\right) \delta 207.8,153.1,114.9,99.3,40.6,30.1,20.9$

MS (ES) $234\left[\left(\mathrm{M}+\mathrm{NH}_{4}\right)^{+}, 100 \%\right]$;

HRMS 234.600 $\left(\mathrm{M}+\mathrm{NH}_{4}, 100 \%, \mathrm{C}_{13} \mathrm{H}_{20} \mathrm{O}_{1} \mathrm{~N}_{3}\right.$ requires 234.1601.

Preparation of tricycle 7

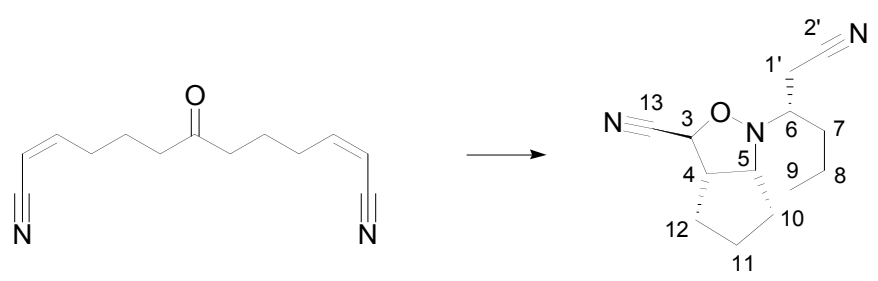

To a solution of 7-oxo-trideca-2,11-dienedinitrile 6 (1.7 mmol, $367 \mathrm{mg}$, 1eq) in anhydrous methanol $(20 \mathrm{~mL})$ and acetonitrile $(2 \mathrm{~mL})$ was added hydroxylamine hydrochloride (1.87 mmol, $129 \mathrm{mg}, 1.1 \mathrm{eq})$ and sodium acetate $(1.87 \mathrm{mmol}, 129 \mathrm{mg}, 3 \mathrm{eq})$ and the resulting solution was stirred at room temperature overnight before being refluxed for 4 hours. The solvent was evaporated and the resulting residue was redissolved in DCM $(20 \mathrm{~mL})$, washed with saturated brine $(10 \mathrm{~mL})$, dried $\left(\mathrm{Na}_{2} \mathrm{SO}_{4}\right)$ and concentrated. The resulting solid was purified by column chromatography over silica gel, eluting with 10:1 hexane:ethyl acetate to give product as a white crystalline solid (1.5 mmol, $349 \mathrm{mg}, 89 \%)$.

6( $\left(S^{*}\right)$-Cyanomethyl-3 $\left(S^{*}\right)$-cyano-5 $\left(S^{*}\right)$-aza-3 $\left(S^{*}\right)$-oxotricylce[6.4.0.0 $\left.0^{1,5}\right]$ dodecane (7)

$\mathrm{mp}=80.1-81.7^{\circ} \mathrm{C}$ (from heptane)

IR ( NaCl, thin film) $/ \mathrm{cm}^{-1} 2249(\mathrm{CN}), 2218(\mathrm{CN})$

1H NMR (400 MHz, $\left.\mathrm{CDCl}_{3}\right) \delta 4.91(1 \mathrm{H}, \mathrm{d}, J$ 9.2), $2.85(1 \mathrm{H}, \mathrm{t}, J$ 7.6), $2.78(1 \mathrm{H}, \mathrm{dd}, J$ 16.4 and 3.2), 2.68 (1H, ddt $J 19.2,8.0$ and 2.8), 2.53 (1H, dd, $J 8.8$ and 8.0), 2.13-1.17 $(12 \mathrm{H}, \mathrm{m})$

13C NMR $\left(100 \mathrm{MHz}, \mathrm{CDCl}_{3}\right) \delta 117.8,116.0,78.5,68.9,58.3,50.9,40.4,33.0,29.0$, $28.9,23.6,23.1,20.2$

MS (ES), $249\left(\mathrm{M}+\mathrm{NH}_{4}, 100 \%\right), 232(85)$

HRMS found 232.145, $\mathrm{C}_{13} \mathrm{H}_{18} \mathrm{ON}_{3}$ requires 232.1450. 


\section{Preparation of [6.6.5] tricycle 8}

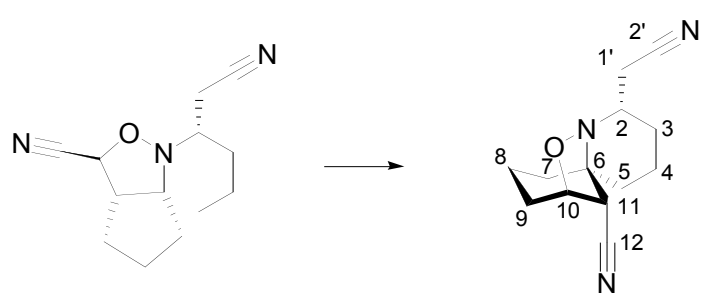

A solution of $7(0.19 \mathrm{mmol}, 44 \mathrm{mg}, 1 \mathrm{eq})$ in anhydrous toluene $(10 \mathrm{~mL})$ was heated at 180 ${ }^{\circ} \mathrm{C}$ in a sealed tube for 2.5 hours. The reaction was cooled to room temperature and the solvent was evaporated. The product was then purified by column chromatography over silica gel, eluting with 2:1 hexane:ethyl acetate to give product as an opaque crystalline solid (0.18 mmol, $42 \mathrm{mg}, 95 \%)$.

2( $\left(S^{*}\right)$-Cyanomethyl-11( $\left.S^{*}\right)$-cyano-6 $\left(S^{*}\right)$-aza-10 $\left(S^{*}\right)$-oxatricyclo-[6.3.1.0 $\left.{ }^{1,6}\right]$-dodecane $(8)$

IR $\left(\mathrm{NaCl}\right.$, thin film) $/ \mathrm{cm}^{-1} 2238,2208$

$1 \mathrm{H} \mathrm{NMR}\left(400 \mathrm{MHz} ; \mathrm{CDCl}_{3}\right) \delta 4.72(1 \mathrm{H}, \mathrm{d}, J 2.2), 3.36(1 \mathrm{H}, \mathrm{dd}, J 6.4$ and 2.2), $2.75(2 \mathrm{H}$, m), 2.55 (1H, q, $J 8.0), 2.23$ (2H, dt, $J 16.0$ and 2.0), 2.00-0.90 (10H, m)

13C NMR (100 MHz, $\left.\mathrm{CDCl}_{3}\right) \delta 130.9,128.8,109.8,76.1,38.7,38.2$, 30.3, 29.6, 28.9, $23.1,23.0,14.1,11.0$

MS (ES) $232(\mathrm{M}+\mathrm{H}, 100 \%)$

HRMS found 232.1453, $\mathrm{C}_{13} \mathrm{H}_{18} \mathrm{ON}_{3}$ requires 232.1450.

Anal. Calc. for $\mathrm{C}_{13} \mathrm{H}_{17} \mathrm{~N}_{3} \mathrm{O}$ : C, 67.51; H, 7.41; N, 18.17\%. Found: C, 67.57; H, 7.31; N, 18.05 . 


\section{Preparation of dialdehyde 9}

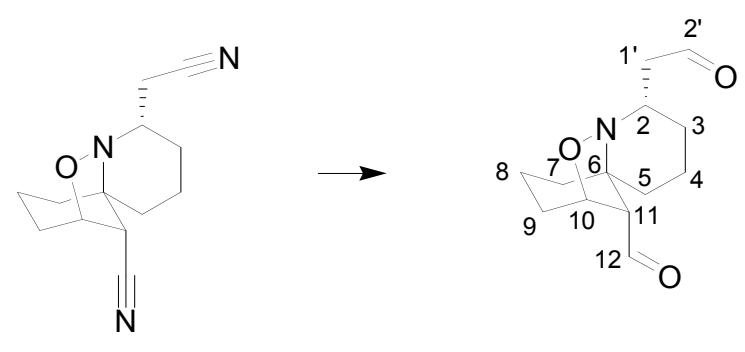

A solution of dinitrile $8(0.37 \mathrm{mmol}, 85 \mathrm{mg}, 1 \mathrm{eq})$ in anhydrous toluene $(5 \mathrm{~mL})$ was cooled to $-78{ }^{\circ} \mathrm{C}$. A $1.5 \mathrm{M}$ solution of DIBAL in toluene $(0.75 \mathrm{mmol}, 0.5 \mathrm{~mL}, 2 \mathrm{eq})$ was then added dropwise and the resulting solution was stirred at $-78^{\circ} \mathrm{C}$ for 2 hours. Methanol $(0.2 \mathrm{~mL})$ was then added and the solution was warmed to room temperature where a solution of Rochelle's salt $(5 \mathrm{~mL})$ was then added. The resulting solution was then stirred for a further 30 minutes and the product was extracted with ethyl acetate $(5 \mathrm{x} 5 \mathrm{~mL})$, dried $\left(\mathrm{Na}_{2} \mathrm{SO}_{4}\right)$ and concentrated to give crude product as a colourless oil. Crude dialdehyde 9 was purified by passing the crude through a short silica plug (deactivated with acetone and packed with EtOAc and eluted with EtOAc) and used immediately (0.36 mmol, $84.6 \mathrm{mg}, 97 \%)$.

2( $\left(S^{*}\right)$-Oxo-ethyl-6 $\left(S^{*}\right)$-aza-10 $\left(S^{*}\right)$-oxatricyclo-[6.3.1.0 $\left.0^{1,6}\right]$-dodecane-11( $\left.\mathrm{S}^{*}\right)$-carbaldehyde

IR $(\mathrm{NaCl}$, thin film $) / \mathrm{cm}-11716(\mathrm{C}=\mathrm{O})$

1H NMR (400 MHz; $\left.\mathrm{CDCl}_{3}\right) \delta 9.79(1 \mathrm{H}, \mathrm{d}, \mathrm{J} 2.4), 9.41(1 \mathrm{H}, \mathrm{dd}, \mathrm{J} 2.0$ and 2.0), $4.13(1 \mathrm{H}$, tt, J 5.4 and 5.4), $3.46(1 \mathrm{H}, \mathrm{m}), 2.82$ (dddd, J 9.0, 6.4, 5.2 and 2.8), 2.76 (1H, ddt, J 9.0, 5.0 and 2.2), $2.51(1 \mathrm{H}, \mathrm{dd}, \mathrm{J} 9.0$ and 6.4), 2.24-1.20 (12H, m)

13C NMR (100 MHz, $\left.\mathrm{CDCl}_{3}\right) \delta 204.9,201.0,80.2,76.2,59.1,52.8,46.9,33.0,28.7$, 26.4, 25.3, 21.2 and 18.7. 


\section{Preparation of bis-Wittig adduct 11}

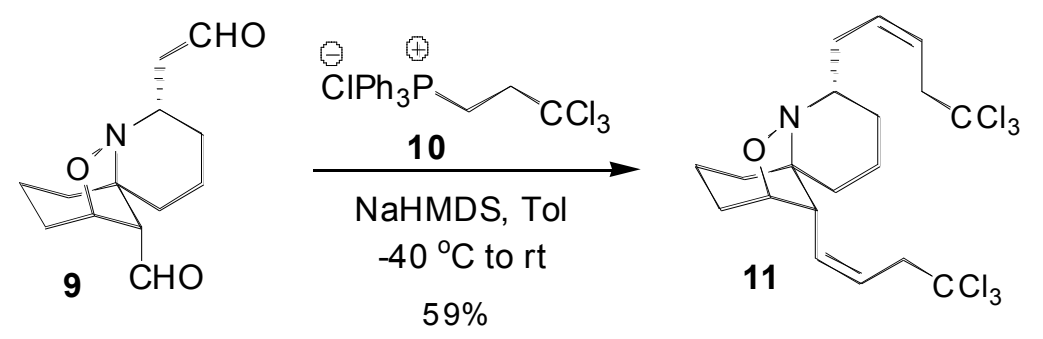

Phosphonium chloride 10 (200 mg, $0.45 \mathrm{mmol}, 4.5 \mathrm{eq})$ was taken in freshly distilled toluene $(2.3 \mathrm{ml})$ and cooled to $-40{ }^{\circ} \mathrm{C}$. To the cooled suspension, $0.4 \mathrm{ml}$ NaHMDS (0.4 mmol, 4 eq) in THF was added dropwise and the mixture was stirred for 20 min at -40 ${ }^{\circ} \mathrm{C}$. The suspension turned dark brown after stirring for $20 \mathrm{~min}$. At this point dialdehyde 9 (24.6 $\mathrm{mg}, 0.1 \mathrm{mmol}$ in $2.3 \mathrm{ml}$ toluene) was cannulated to the ylide solution and mixture allowed to warmup to $10{ }^{\circ} \mathrm{C}$ and stirred over a $12 \mathrm{~h}$ period. Saturated $\mathrm{NH}_{4} \mathrm{Cl}(2 \mathrm{ml})$ was added and product extracted with ethyl acetate $(3 \times 5 \mathrm{ml})$, dried, and concentrated to afford crude product which was purified by short silica column (packed with $10 \%$ EtOAchexane and eluted with 10\% EtOAc-hexane) to obtain $30.4 \mathrm{mg}$ (59\%) of $\mathbf{1 1 .}$

[12-(4,4,4-Trichloro-but-1-enyl)5-(5,5,5,-trichloro-pent-2-enyl)-7-oxa-6-azatricyclo[6.3.1.0 $\left.{ }^{1,6}\right]$ dodecane]-11

${ }^{1} \mathrm{H}$ NMR $\left(300 \mathrm{MHz}, \mathrm{CDCl}_{3}\right) \delta 5.89(\mathrm{~d}, \mathrm{~J}=5 \mathrm{~Hz}, 2 \mathrm{H}), 5.86(\mathrm{~m}, 1 \mathrm{H}), 5.70(\mathrm{~m}, 1 \mathrm{H}), 4.44(\mathrm{~s}$, br, 1H), 3.54 (m, 1H), 3.47 (m, 2H), 3.40 (m, 2H), 2.76 (m, 2H), 2.221 (m, 1H).

${ }^{13} \mathrm{C}$ NMR $\left(75 \mathrm{MHz}, \mathrm{CDCl}_{3}\right) \delta 17.78,19.75,22.69,25.12,29.70,31.92,32.28,32.91$, $34.21,43.26,52.71,52.87,64.54,65.08,78.04,98.22,99.15,123.53,126.07,130.33$, 132.79 .

HRMS (CI) m/z, 458.0374 (458.0379 calcd for $\mathrm{C}_{19} \mathrm{H}_{25} \mathrm{Cl}_{5} \mathrm{NO}, \mathrm{M}+\mathrm{H}^{+}-\mathrm{HCl}$ )

\section{Wittig reaction of aldehydes 12 and 13}

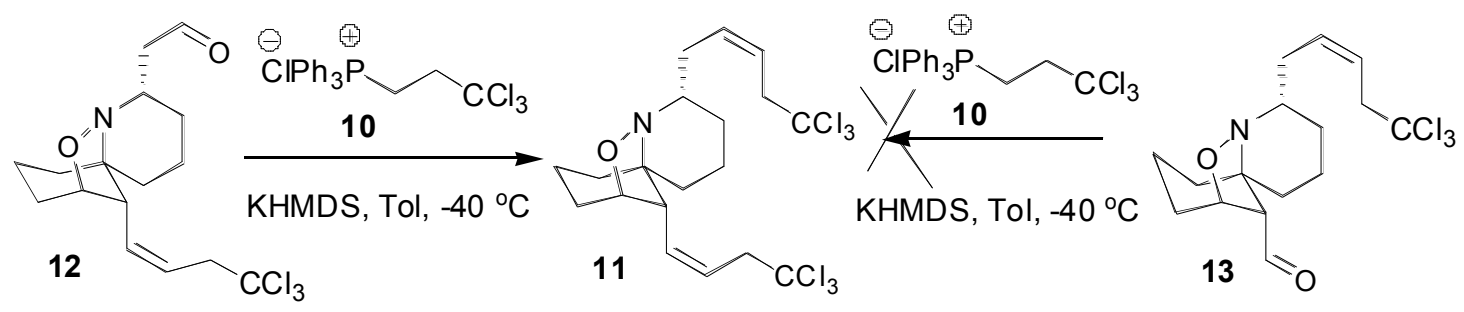


Phosphonium chloride 10 (20 mg, $0.045 \mathrm{mmol}, 2.4 \mathrm{eq})$ was taken in freshly distilled toluene $(0.5 \mathrm{ml})$ and cooled to $-40{ }^{\circ} \mathrm{C}$. To the cooled suspension, $0.07 \mathrm{ml}$ 0.5M KHMDS in Toluene $(0.038 \mathrm{mmol}, 2 \mathrm{eq})$ was added dropwise and the mixture was stirred for 20 min at $-40{ }^{\circ} \mathrm{C}$. The suspension turned dark brown after stirring for $20 \mathrm{~min}$. At this point aldehyde 12 (4.5 mg, $0.019 \mathrm{mmol}, 1 \mathrm{eq}$ in $0.5 \mathrm{ml}$ toluene) was cannulated to the ylide solution and mixture allowed to stir for another $2 \mathrm{~h}$. Saturated $\mathrm{NH}_{4} \mathrm{Cl}(0.5 \mathrm{ml})$ was added and product extracted with ethyl acetate, dried, and concentrated to afford crude product which was purified by short silica column (1:9 EtOAc:hexane) to obtain $1.3 \mathrm{mg}(21 \%)$ of 11.

Under the same conditions, a parallel reaction of $13(4 \mathrm{mg}, 0.017 \mathrm{mmol}, 1 \mathrm{eq}$ in $0.5 \mathrm{ml}$ toluene) with ylide (generated from 10, $0.04 \mathrm{mmol}, 2.5 \mathrm{eq}$ ) did not produce any new product.

\section{Preparation of tetrachloride 14}

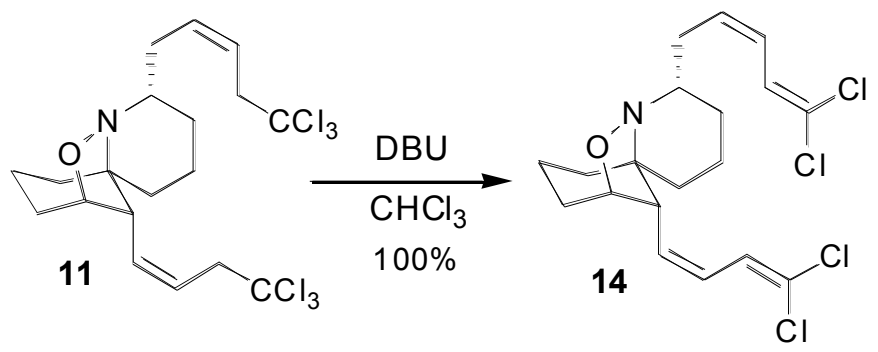

To bis-trichloroalkene 11 (8 mg, $0.016 \mathrm{mmol})$ in $\mathrm{CHCl}_{3}(1 \mathrm{ml}), \mathrm{DBU}$ (1.2 eq) was added and mixture left at $\mathrm{rt}$ for 1 day. ${ }^{1} \mathrm{H}-\mathrm{NMR}$ showed the reaction was complete. $\mathrm{CHCl}_{3}$ was removed and the crude product was passed through a short silica pad (eluted with 1:9 EtOAc-hexane) to afford tetrachloride 14 quantitatively.

[12-(4,4-Dichloro-buta-1,3-dienyl)-5-(5,5-dichloro-penta-2,4-dienyl)-7-oxa-6-azatricyclo[6.3.1.0 $\left.0^{1,6}\right]$ dodecane]-14 
${ }^{1} \mathrm{H}$ NMR $\left(300 \mathrm{MHz}, \mathrm{CDCl}_{3}\right) \delta 6.76(\mathrm{~d}, \mathrm{~J}=11.1 \mathrm{~Hz}, 1 \mathrm{H}), 6.66(\mathrm{~d}, \mathrm{~J}=11.1 \mathrm{~Hz}, 1 \mathrm{H}), 6.36(\mathrm{t}$, $\mathrm{J}=10.8 \mathrm{~Hz}, 1 \mathrm{H}), 6.21$ (t, J=10.8 Hz, 1H), 5.73 (t, J=10.2 Hz, 10.5 Hz, 2H), 4.45 (m, 1H), $3.42(\mathrm{dd}, \mathrm{J}=6.3 \mathrm{~Hz}, 9.9 \mathrm{~Hz}, 1 \mathrm{H}), 2.75(\mathrm{~m}, 2 \mathrm{H}), 2.26(\mathrm{~m}, 1 \mathrm{H}), 1.97$ (m, 1H).

${ }^{13} \mathrm{C}$ NMR $\left(75 \mathrm{MHz}, \mathrm{CDCl}_{3}\right) \delta 17.77,19.55,22.68,25.06,29.35,29.63,29.69,32.19$, $33.43,34.31,43.98,64.51,65.39,78.19,121.92,123.75,124.24,124.53,124.82,126.42$, $129.42,132.47$.

HRMS (CI) m/z, 422.0610 (422.0612 calcd for $\mathrm{C}_{19} \mathrm{H}_{24} \mathrm{Cl}_{4} \mathrm{NO} \mathrm{M}+\mathrm{H}^{+}$)

\section{Preparation of dichloro-dienyne 15}

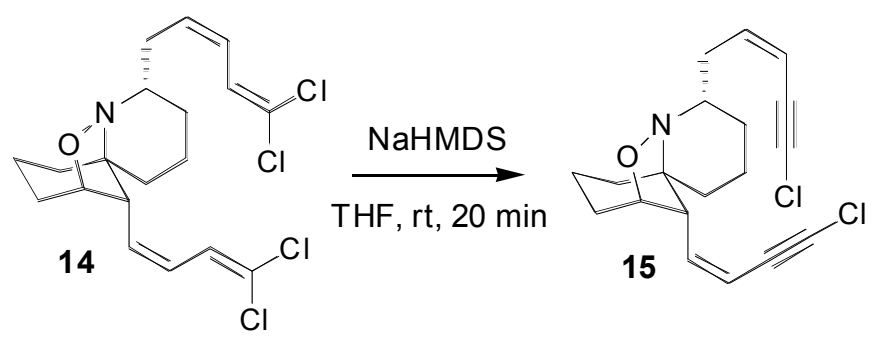

tetrachloride $14(6 \mathrm{mg}, 0.014 \mathrm{mmol})$ was taken in THF $(1 \mathrm{ml})$ and cooled to $0{ }^{\circ} \mathrm{C}$. To the cooled solution, NaHMDS in THF $(0.08 \mathrm{ml}, 6 \mathrm{eq})$ was added dropwise and the mixture was allowed to warm to rt and stirred for $20 \mathrm{~min}$. TLC (3:7 EtOAc:hexane) showed the reaction was complete, the reaction was quenched with sat. $\mathrm{NH}_{4} \mathrm{Cl}$, and the product extracted with ethyl acetate. Pure product $4.5 \mathrm{mg}$ (90\%) of 15 was obtained by passing crude product through a column of acetone-deactivated silica (eluted with 1:9 EtOAchexane).

[12-(4-Chloro-but-1-en-3-ynyl)-5-(5-chloro-pent-2-en-4-ynyl)-7-oxa-6-azatricyclo[6.3.1.0 $\left.0^{1,6}\right]$ dodecane]-15

${ }^{1} \mathrm{H}$ NMR (300MHz, $\left.\mathrm{CDCl}_{3}\right) \delta 6.09(\mathrm{~m}, 2 \mathrm{H}), 5.64$ (d, J=10.5 Hz, 1H), 5.47 (d, $10.8 \mathrm{~Hz}$, 1H), 4.49 (t, J=10.8 Hz, 1H), 3.77 (dd, J=8.2 Hz, $7.2 \mathrm{~Hz}, 1 \mathrm{H}), 2.8$ (m, 3H), 2.5 (t,t, J=8.4 $\mathrm{Hz}, 5.7 \mathrm{~Hz}, 8.4 \mathrm{~Hz}, 2 \mathrm{H}), 1.96$ (m, 3H).

${ }^{13} \mathrm{C}$ NMR $\left(75 \mathrm{MHz}, \mathrm{CDCl}_{3}\right) \delta 17.98,19.68,25.34,29.77,29.97,32.53,34.68,35.60$, 46.36, 64.26, 66.09, 66.51, 66.80, 71.26, 72.68, 109.64, 111.93, 139.84, 143.02.

HRMS (CI) m/z, 350.1077 (350.1078 calcd for $\mathrm{C}_{19} \mathrm{H}_{22} \mathrm{Cl}_{2} \mathrm{NO}, \mathrm{M}+\mathrm{H}^{+}$) 


\section{Synthesis of $( \pm)$ HTX 1}

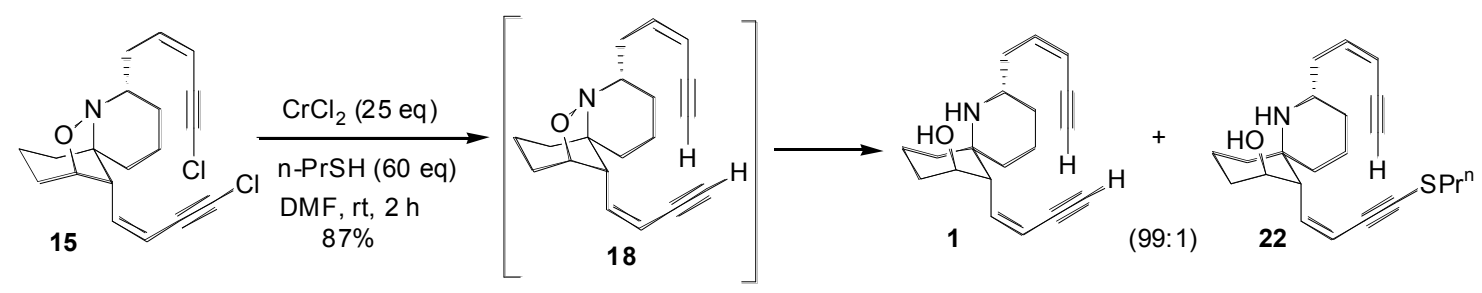

Bis-chloroenyne $15(9.7 \mathrm{mg}, 0.028 \mathrm{mmol})$ was taken in DMF (1.2 ml) along with npropanethiol $(0.15 \mathrm{ml}, 1.66 \mathrm{mmol}, 60 \mathrm{eq})$. The solution was stirred at $\mathrm{rt}$ under nitrogen. $\mathrm{CrCl}_{2}(87 \mathrm{mg}, 25 \mathrm{eq})$ was added in one portion and the green solution was stirred vigorously. Within the first 5-10 min, starting material was consumed and the formation of 18 was evident from the TLC (3:7 EtOAc-hexane). After stirring for $2 \mathrm{~h}$, the reaction was complete, water $(1 \mathrm{ml})$ was added, and the product extracted with ethyl acetate $(3 \times 5$ $\mathrm{ml}$ ). The crude product was column chromatographed on deactivated silica (packed with 10\% EtOAc-hexane and eluted with 10\%, 20\%, 40\%, 100\% EtOAc followed by 1\%, 10\%, 20\% MeOH-EtOAc) to afford $6.7 \mathrm{mg}$, (87\%) of HTX 1 (containing <1\% 22).

[7-But-1-en-3-ynyl-2-pent-2-en-4-ynyl-1-aza-spiro[5,5] undecan-8-ol]-1

${ }^{1} \mathrm{H}$ NMR $\left(300 \mathrm{MHz}, \mathrm{CDCl}_{3}\right) \delta 6.07(\mathrm{~m}, 1 \mathrm{H}), 5.85(\mathrm{dd}, \mathrm{J}=11.4 \mathrm{~Hz}, \mathrm{~J}=10.5 \mathrm{~Hz}, 1 \mathrm{H}), 5.54$ (m, 2H), $5.31(\mathrm{~d}$, broad, 1H), 3.78 (s, broad, 1H), 3.65 (d, J=9,9 Hz, 1H), 3.14 (d, J=18. $\mathrm{Hz}, 1 \mathrm{H}), 3.07$ (s, 1H).

${ }^{13} \mathrm{C}$ NMR $\left(75 \mathrm{MHz}, \mathrm{CDCl}_{3}\right) \delta 15.14,19.42,28.95,32.46,36.64,37.64,41.43,50.07$, $54.81,71.46,79.82,80.43,81.90,82.78,110.42,110.68,141.54,142.66$.

HRMS $\left(\mathrm{ES}^{+}\right) \mathrm{m} / \mathrm{z}, 284.2016$ (284.2014 calcd for $\mathrm{C}_{19} \mathrm{H}_{25} \mathrm{NO}, \mathrm{M}+\mathrm{H}^{+}$) [2-Pent-2-en-4-ynyl-7-(4-propylsulfanyl-but-1-en-3-ynyl)-1-aza-spiro[5.5] undecan-8-ol] 22

MS $\left(\mathrm{ES}^{+}\right) \mathrm{m} / \mathrm{z} 358$ (358.2 calcd for $\mathrm{C}_{22} \mathrm{H}_{31} \mathrm{NOS}, \mathrm{M}+\mathrm{H}^{+}$) 


\section{Preparation bis-TMS-enyne 16}
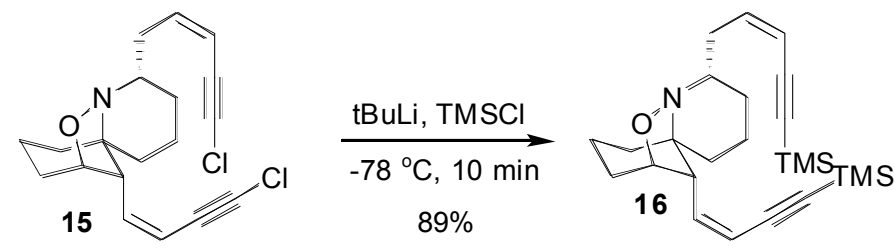

Holmes intermediate

Chloroenyne $15(2.2 \mathrm{mg}, 0.006 \mathrm{mmol})$ was taken in THF $(0.5 \mathrm{ml})$ and cooled to $-70{ }^{\circ} \mathrm{C}$. To the cooled solution, $0.8 \mathrm{M}$ t-BuLi $(0.03 \mathrm{ml}, 4 \mathrm{eq})$ was added dropwise. The yellow color became permanent after complete addition and TLC (3:7 EtOAc:hexane) showed the disappearance of the starting material. This metallated enyne was quenched at the same temperature with $\mathrm{TMSCl}(0.01 \mathrm{ml}, 13 \mathrm{eq})$ that had been stored over polyvinyl pyridine(PVP). Reaction mixture was stirred for 5 min and treated with $\mathrm{NH}_{4} \mathrm{Cl}(0.5 \mathrm{ml})$ and the product was extracted with ether. Crude product was passed through a small plug of acetone-deactivated silica (1:9 EtOAc-hexane as eluent) to obtain $2.4 \mathrm{mg}(89 \%)$ of 16. [12-(4-Trimethylsilanyl-but-1-en-3-ynyl)-5-(5-trimethylsilanyl-pent-2-en-4-ynyl)-7-oxa6-aza-tricyclo[6.3.1.0 $\left.0^{1,6}\right]$ dodecane]-16

${ }^{1} \mathrm{H}$ NMR (300MHz, $\left.\mathrm{CDCl}_{3}\right) \delta 6.04(\mathrm{~m}, 2 \mathrm{H}), 5.69$ (d, J=10.5 Hz, 1H), 5.55 (d, J=10.5 Hz, 1H), 4.49 (t, J=5.2 Hz, 1H), 3.89 (dd, J=8.4 Hz, 8.1 Hz, 1H), 2.79 (m, 2H), 2.55 (m, 1H), $1.97(\mathrm{~m}, 1 \mathrm{H}), 0.17(\mathrm{~d}, \mathrm{~J}=3 \mathrm{~Hz}, 18 \mathrm{H})$.

HRMS (ES ${ }^{+}$) m/z, 426.2653 (426.2648 calcd for $\mathrm{C}_{25} \mathrm{H}_{40} \mathrm{NOSi}_{2}, \mathrm{M}+\mathrm{H}^{+}$)

\section{Preparation of aminoalcohol 20}

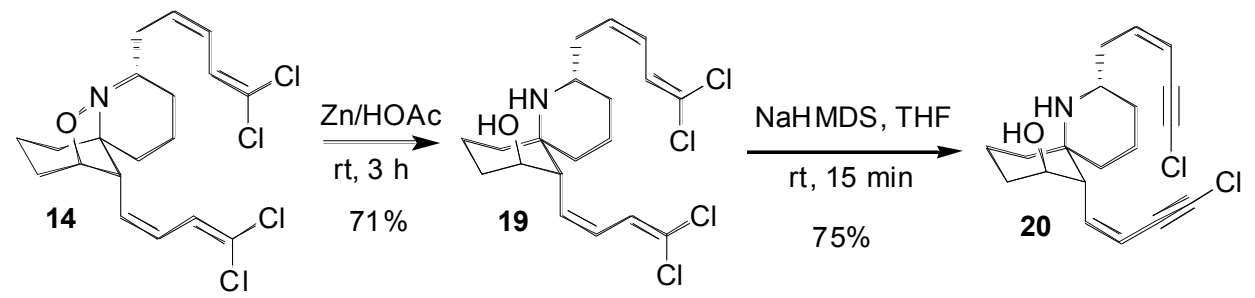

Tetrachloride $14(3.5 \mathrm{mg}, 0.008 \mathrm{mmol})$ was taken in glacial acetic acid $(0.2 \mathrm{ml})$ and activated zinc dust ( $7 \mathrm{mg}, 25 \mathrm{eq}$ ) was added in one portion. The mixture was vigorously stirred for $3 \mathrm{~h}$ at $\mathrm{rt}$. The reaction was almost complete from the TLC (5\% $\mathrm{MeOH}: E t O A c)$. The reaction mixture was quenched by adding ethyl acetate $(3 \mathrm{ml})$ and a 
solution of $\mathrm{NaOAc}_{3} 3 \mathrm{H}_{2} \mathrm{O}\left(1 \mathrm{~g}\right.$ in $\left.2 \mathrm{ml} \mathrm{H} \mathrm{H}_{2} \mathrm{O}\right)$. Acetic acid was carefully neutralized by addition of solid $\mathrm{NaHCO}_{3}(0.4 \mathrm{~g})$. The aqueous layer was separated and extracted with $4 \times 3 \mathrm{ml}$ of ethyl acetate. The combined organic layers were washed with brine $(2 \mathrm{ml})$ and dried $\left(\mathrm{MgSO}_{4}\right)$. The solvent was removed and the residue was purified by passing through a short column of acetone-deactivated silica (eluted with EtOAc followed by 1\% $\mathrm{MeOH}-\mathrm{EtOAc})$ to afford the amino alcohol $19(2.5 \mathrm{mg}, 71 \%)$.

[7(4,4-Dichloro-buta-1,3-dienyl)-2-(5,5-dichloro-penta-2,4-dienyl)-1-azaspiro[5,5] undecan-8-ol]-19

${ }^{1} \mathrm{H}$ NMR (300MHz, $\left.\mathrm{CDCl}_{3}\right) \delta 6.89$ (d, J=11.1 Hz, 1H), 6.74 (d, J=11.1 Hz, 1H), 6.32 (dd, $\mathrm{J}=11.4 \mathrm{~Hz}, 11.2 \mathrm{~Hz}, 2 \mathrm{H}), 5.77$ (dd, J=8.1 Hz, J=7.5 Hz, 2H), 5.57 (t, $11 \mathrm{~Hz}, 3 \mathrm{H}), 3.8$ (s, br, 1H), 3.36 (d, J=10.2 Hz, 1H), 3.18 (m, $1 \mathrm{H})$.

HRMS $\left(\mathrm{ES}^{+}\right) \mathrm{m} / \mathrm{z}, 422.0613$ (422.0612 calcd for $\mathrm{C}_{19} \mathrm{H}_{26} \mathrm{Cl}_{4} \mathrm{NO}, \mathrm{M}+\mathrm{H}^{+}$)

Preparation of amino alcohol 20:

Amino alcohol $19(3.8 \mathrm{mg}, 0.009 \mathrm{mmol})$ was taken in THF $(1 \mathrm{ml})$ and cooled to $0{ }^{\circ} \mathrm{C}$. To this solution NaHMDS in THF $(0.13 \mathrm{ml}, 14 \mathrm{eq})$ was added dropwise and the mixture was brought to $\mathrm{rt}$ and stirred for $15 \mathrm{~min}$. TLC (5\% MeOH-EtOAc) showed reaction completion. $\mathrm{NH}_{4} \mathrm{Cl}(1 \mathrm{ml})$ was added and product extracted with ethyl acetate. The organic layer was dried and concentrated to give crude product which was passed through a short column of acetone-deactivated silica (eluted with EtOAc followed by $1 \% \mathrm{MeOH}-$ EtOAc) to afford $2.2 \mathrm{mg}(70 \%)$ of amino alcohol 20.

[7(4-Chloro-but-1-en-3-ynyl)-2-(5-chloro-pent-2-en-4-ynyl)-1-aza-spiro[5,5]ndecanol]-

\section{0}

${ }^{1} \mathrm{H}$ NMR $\left(300 \mathrm{MHz}, \mathrm{CDCl}_{3}\right) \delta 6.32(\mathrm{~d}, \mathrm{~J}=9.9 \mathrm{~Hz}, 1 \mathrm{H}), 5.96(\mathrm{~m}, 2 \mathrm{H}), 5.47$ (d, J=10.2 Hz, 1H), $5.17(\mathrm{~s}, 1 \mathrm{H}), 3.66(\mathrm{~m}, 1 \mathrm{H}), 3.22(\mathrm{~m}, 1 \mathrm{H}), 2.43(\mathrm{t}, \mathrm{J}=7.2 \mathrm{~Hz}, 7.5 \mathrm{~Hz}, 2 \mathrm{H})$. HRMS $\left(\mathrm{ES}^{+}\right) \mathrm{m} / \mathrm{z}, 352.1231$ (352.1235 calcd for $\mathrm{C}_{19} \mathrm{H}_{24} \mathrm{Cl}_{2} \mathrm{NO}, \mathrm{M}+\mathrm{H}^{+}$) 


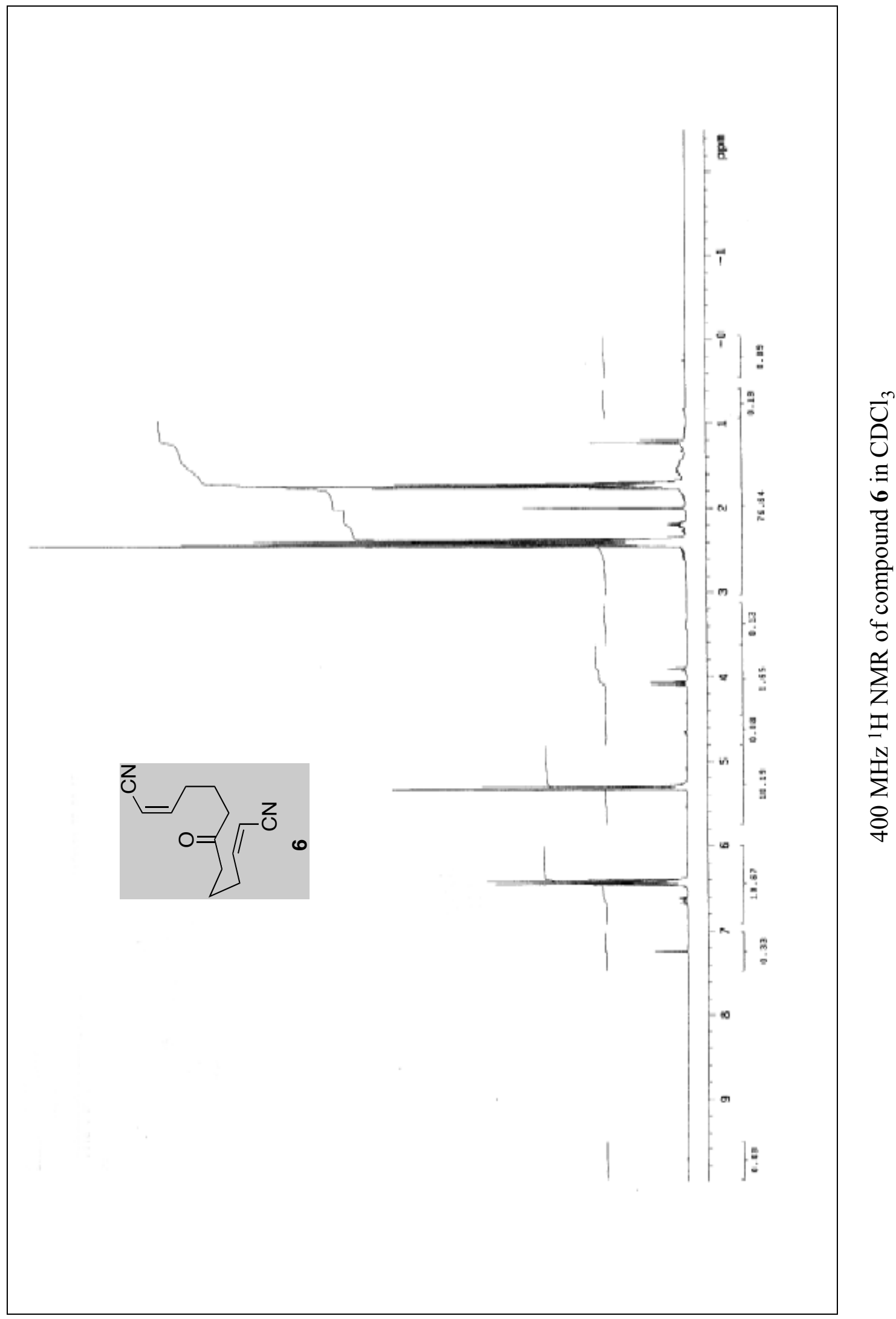




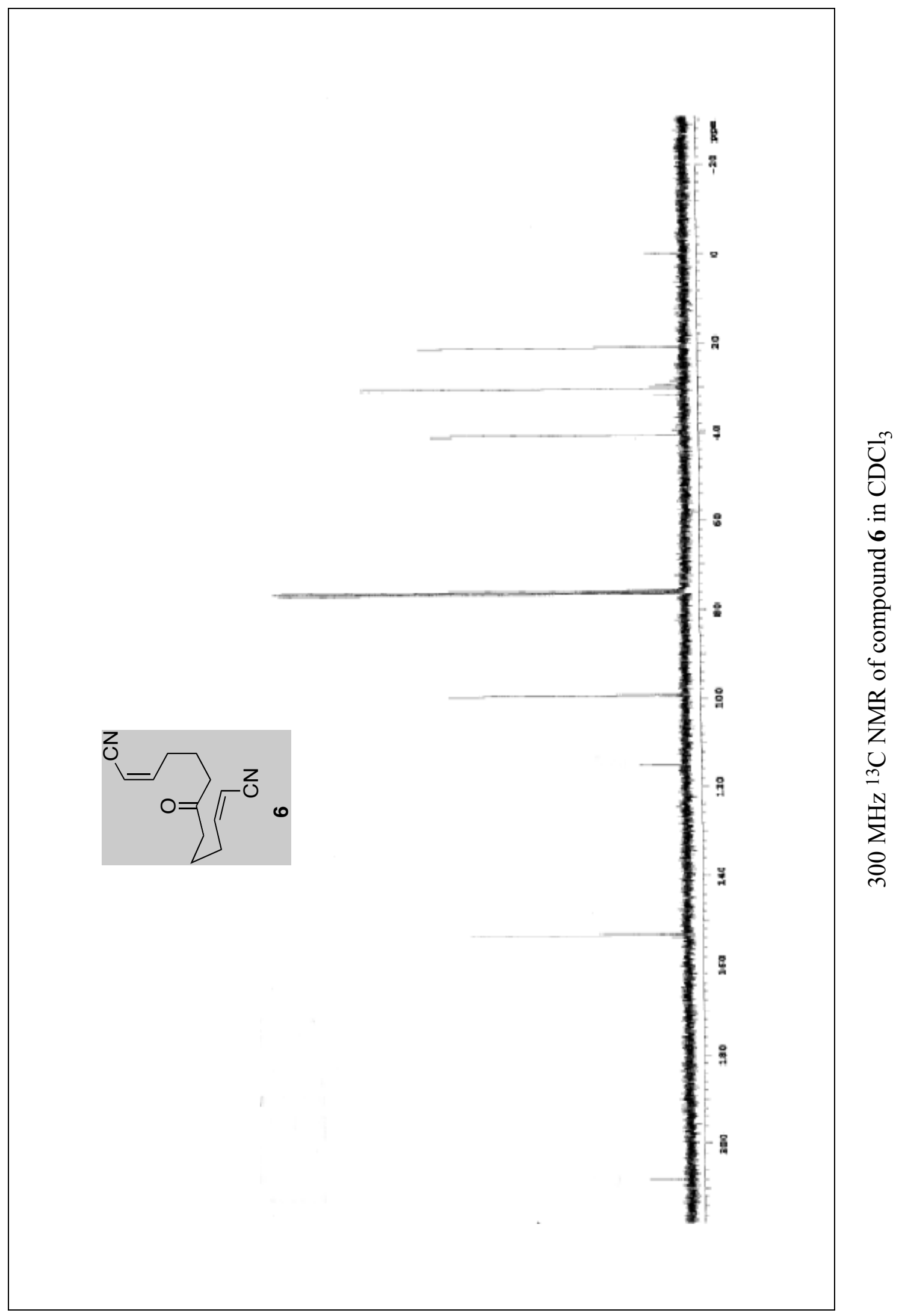




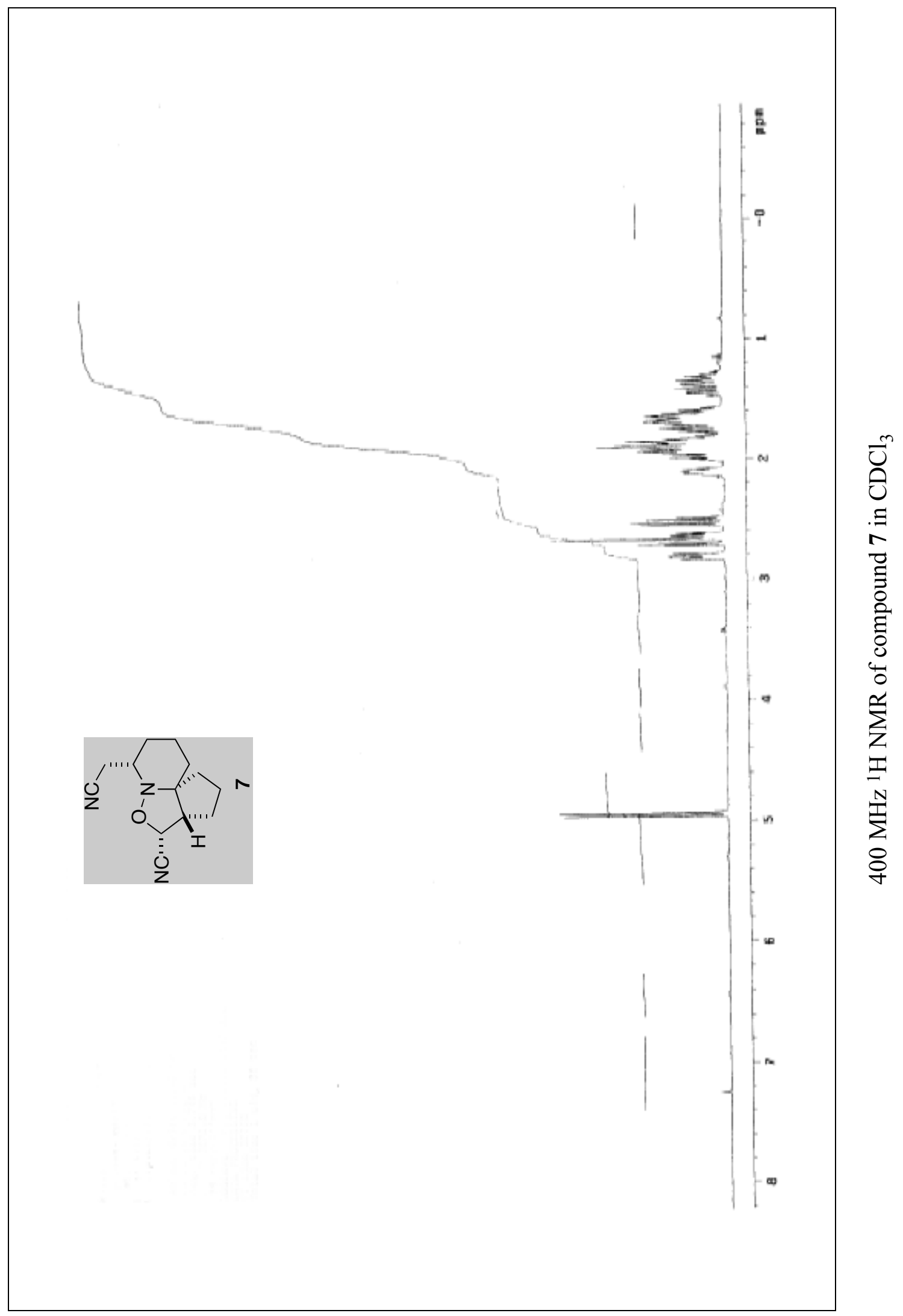




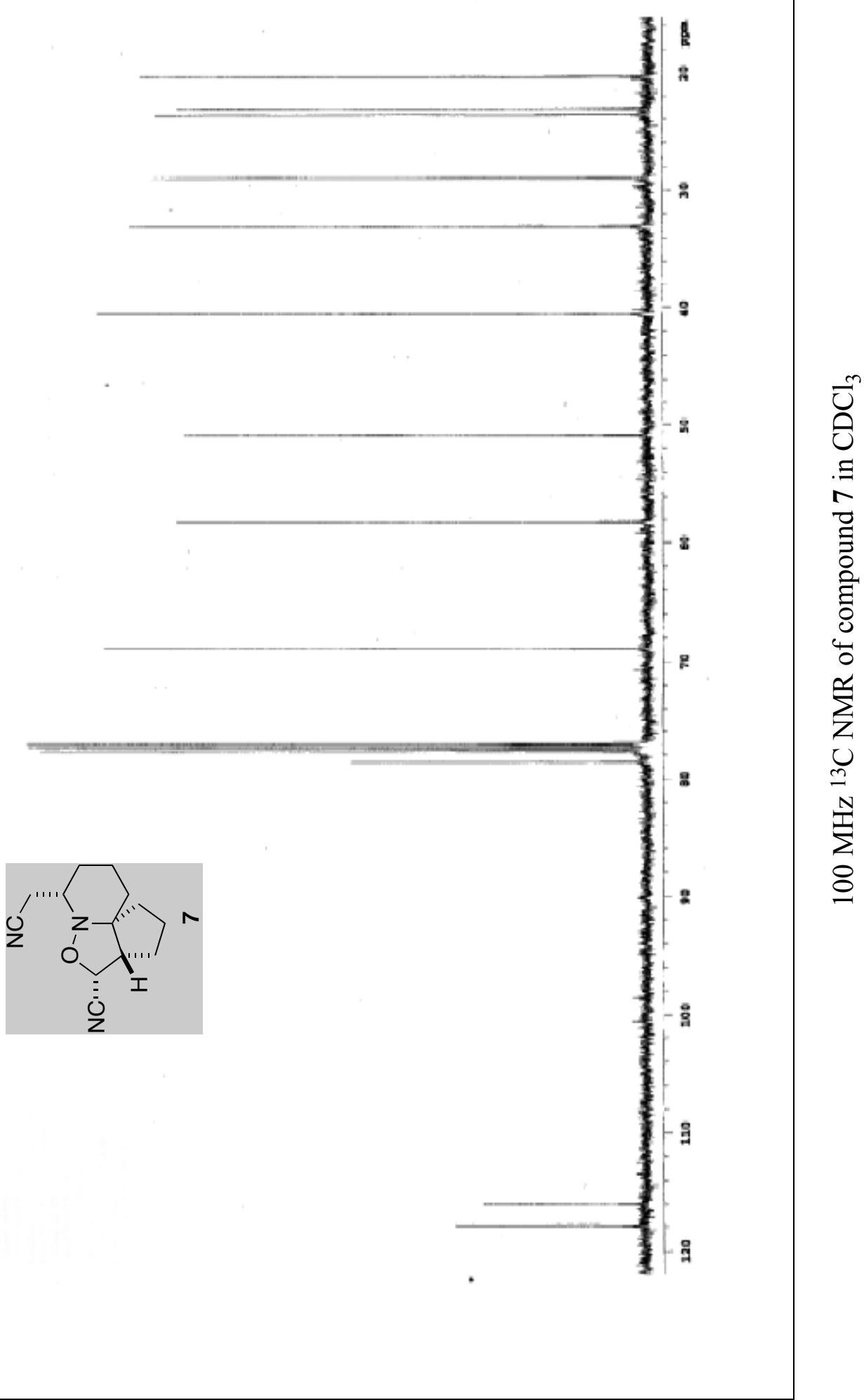




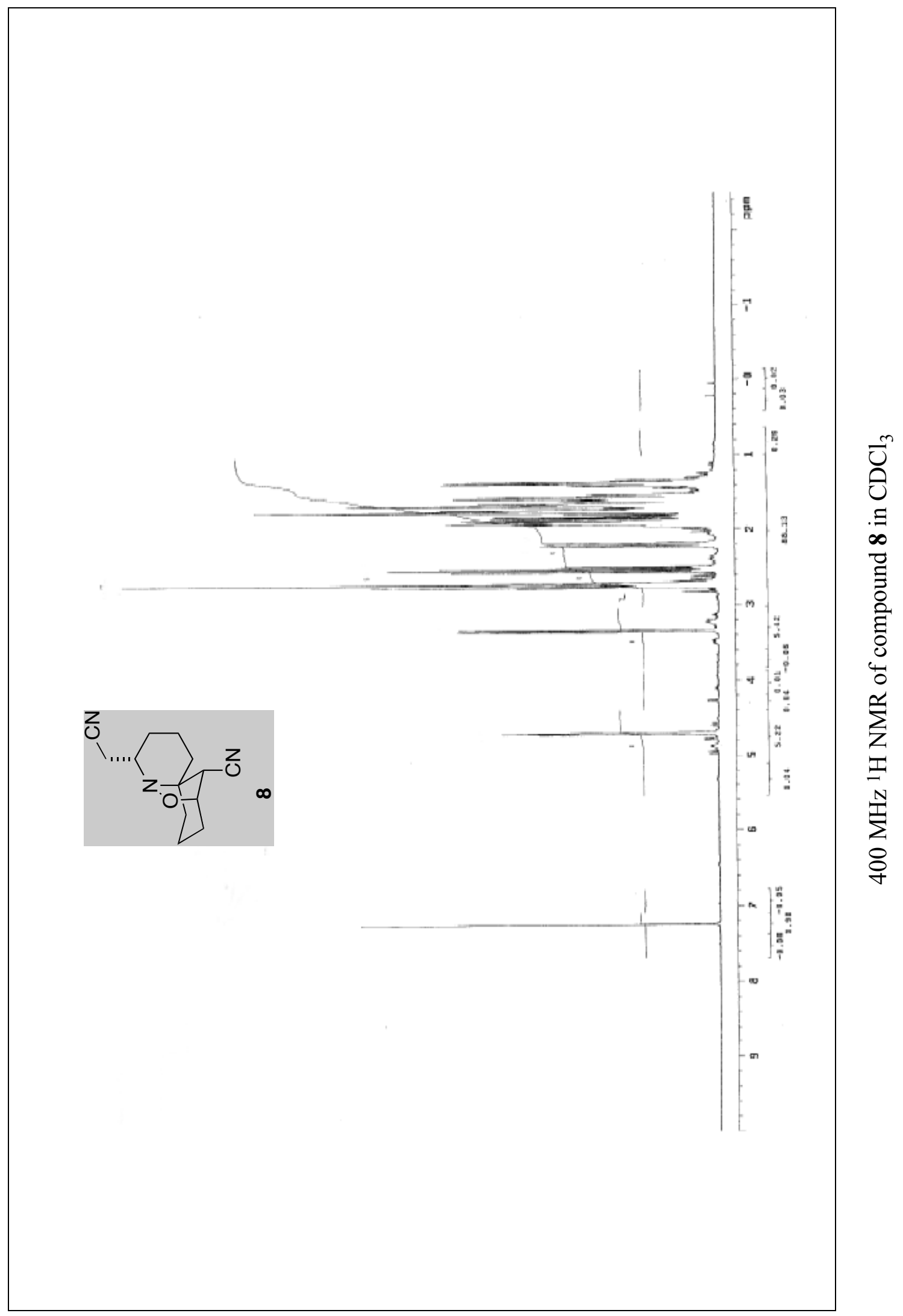




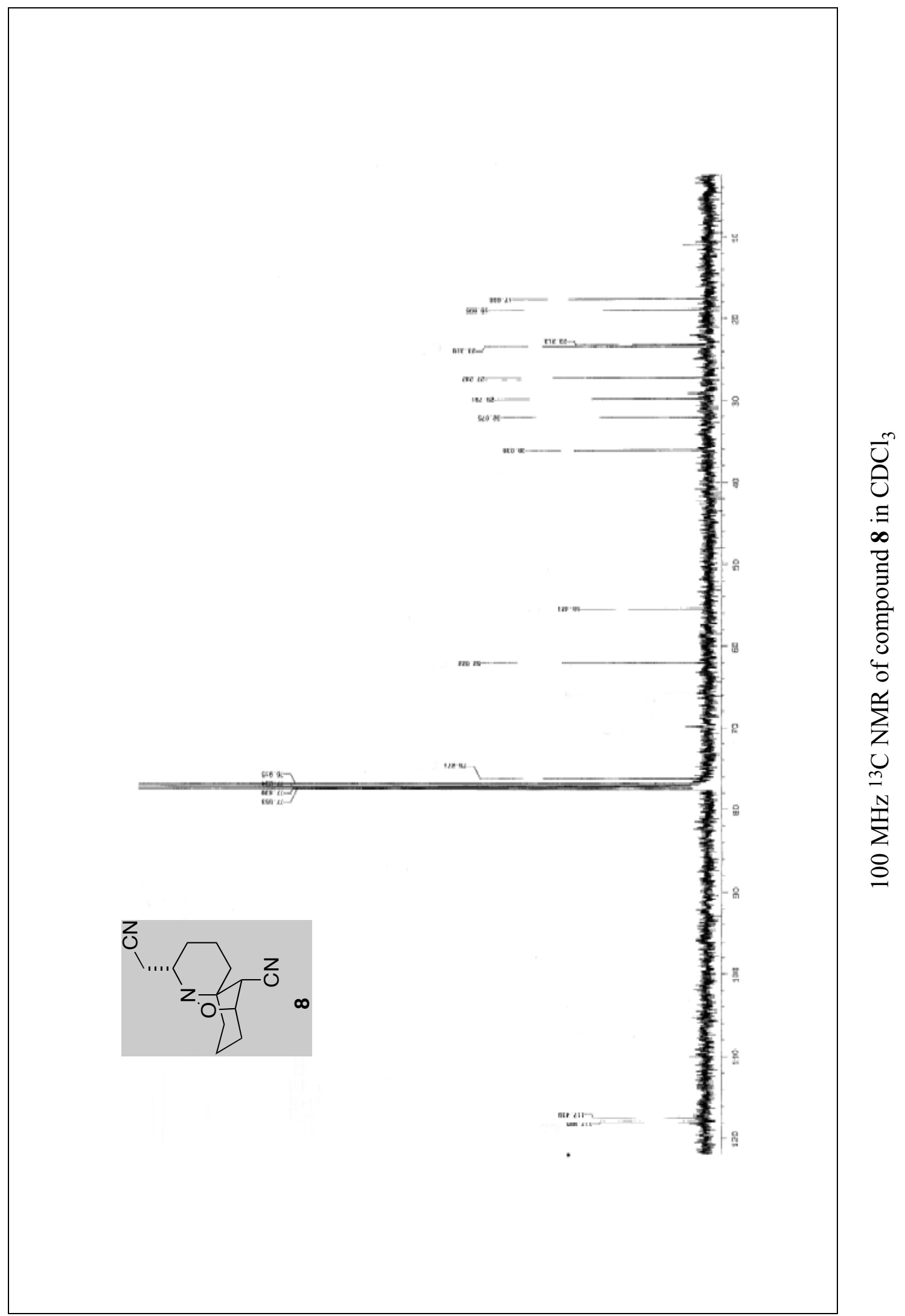




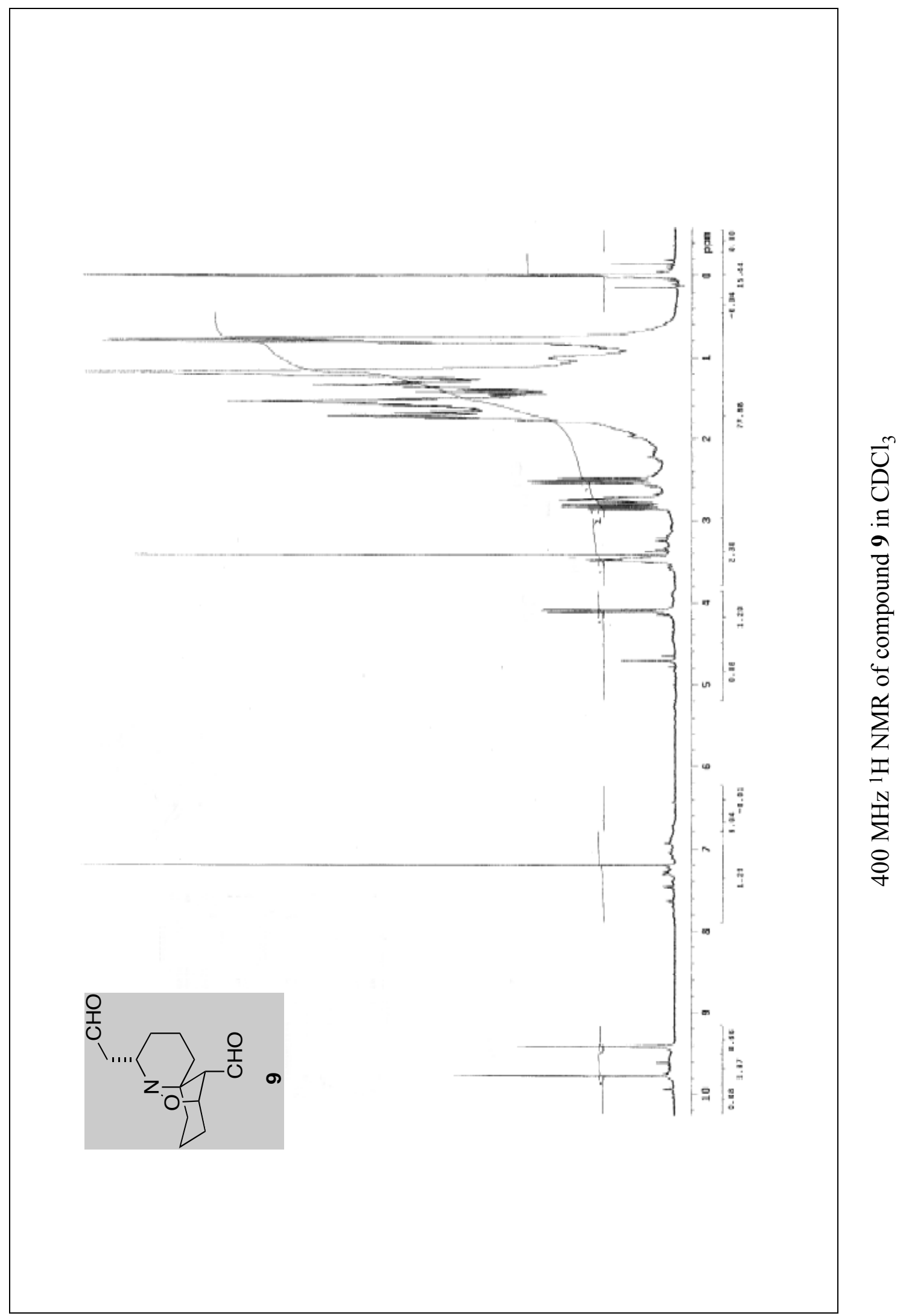




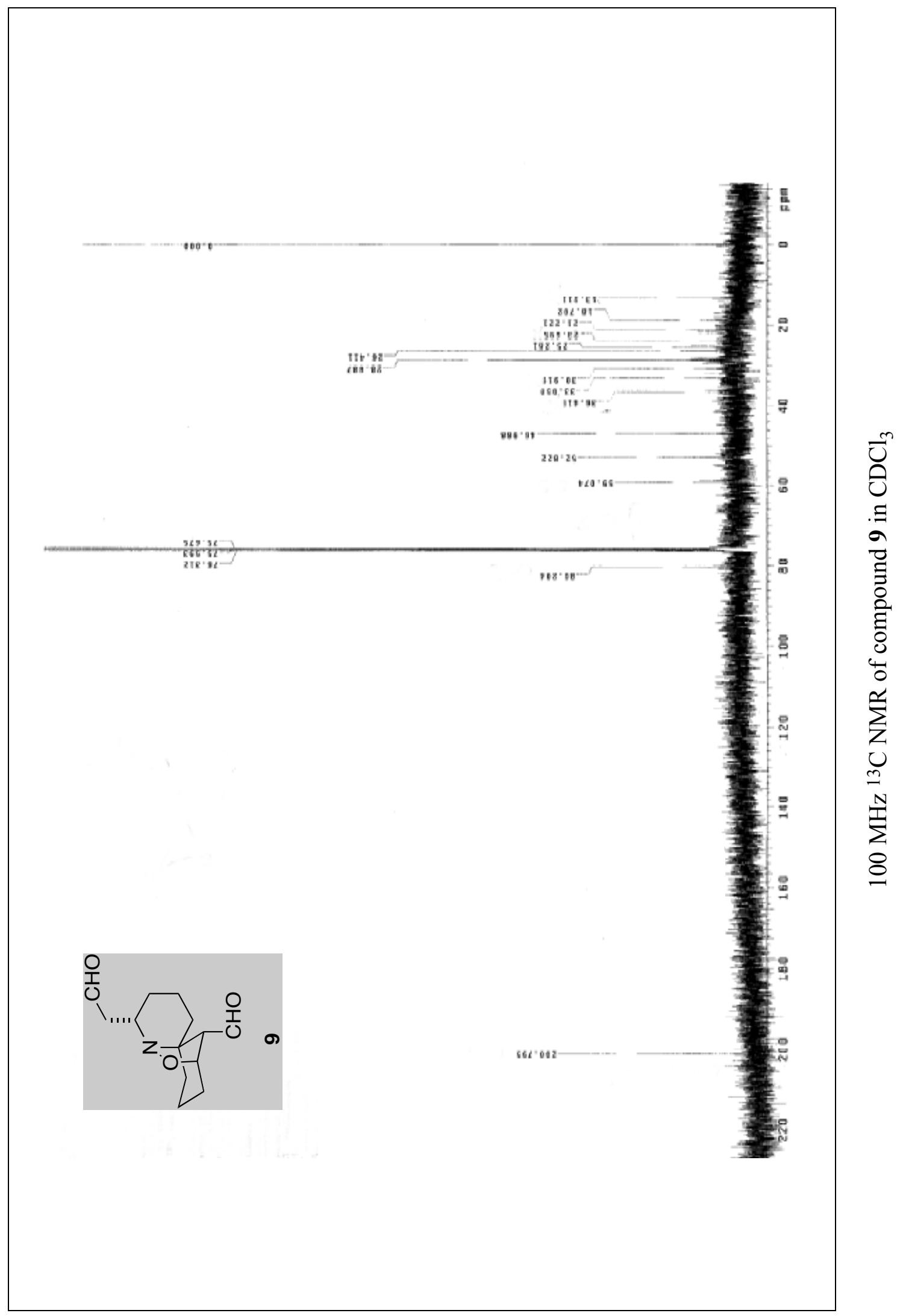




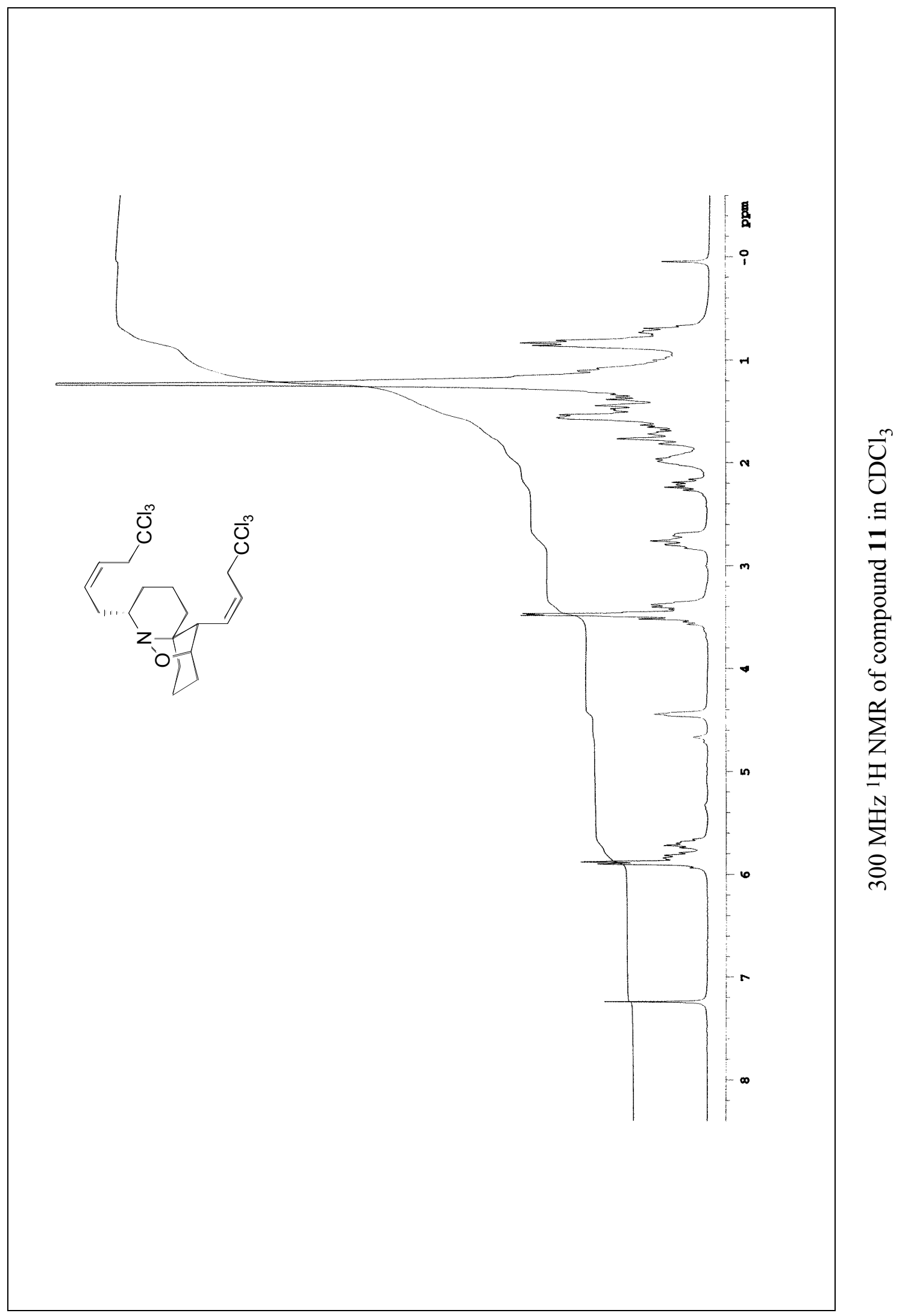




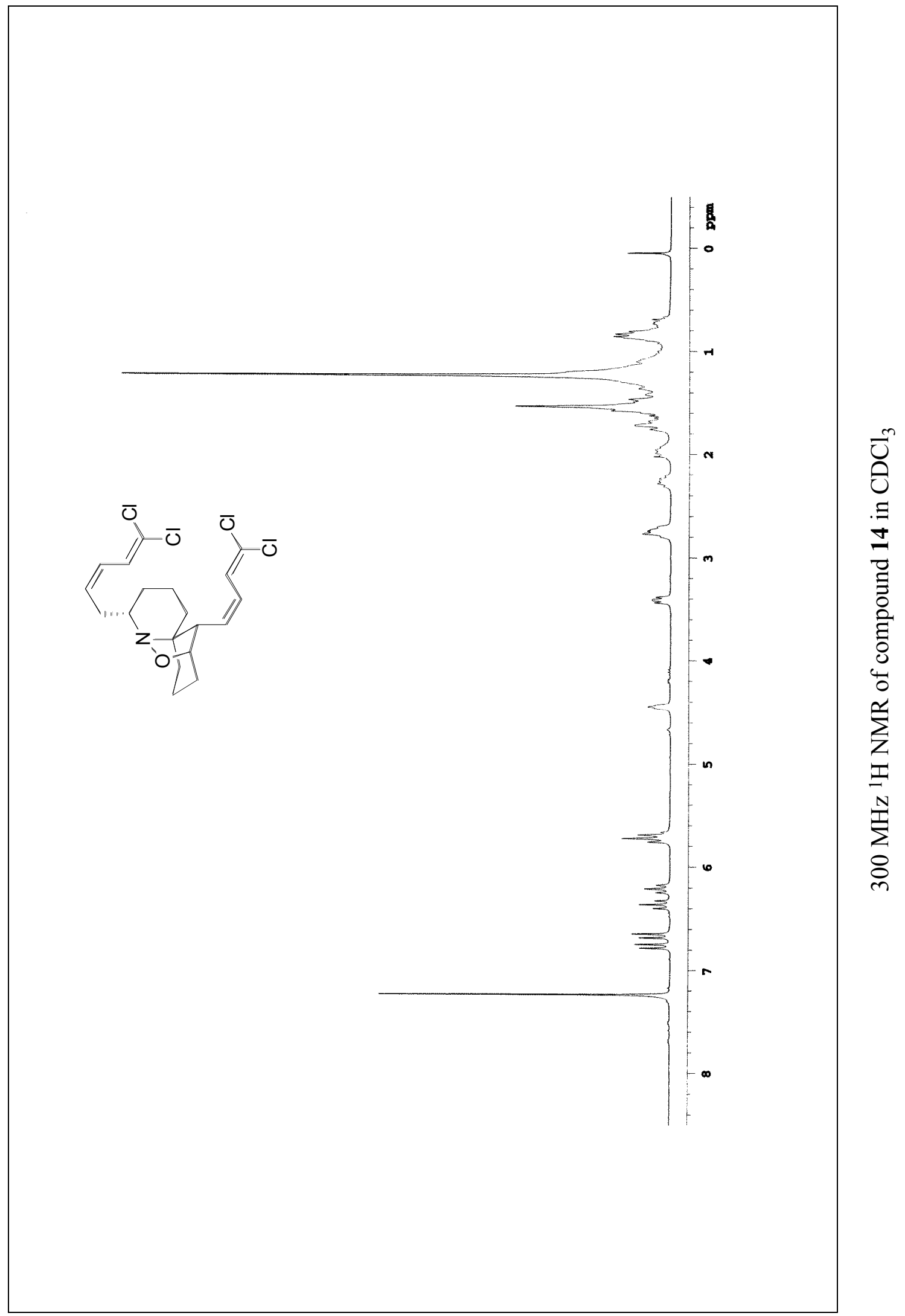




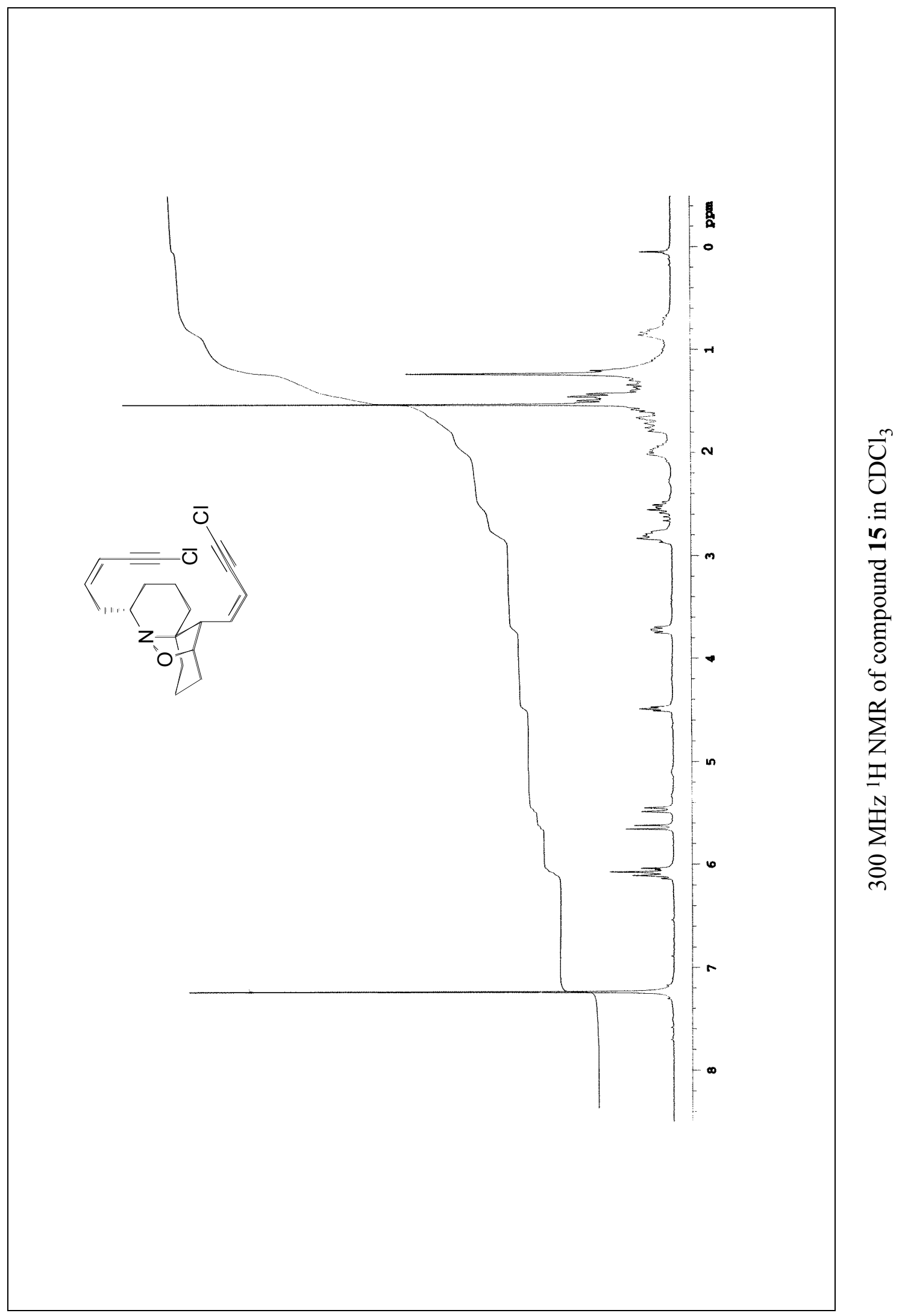




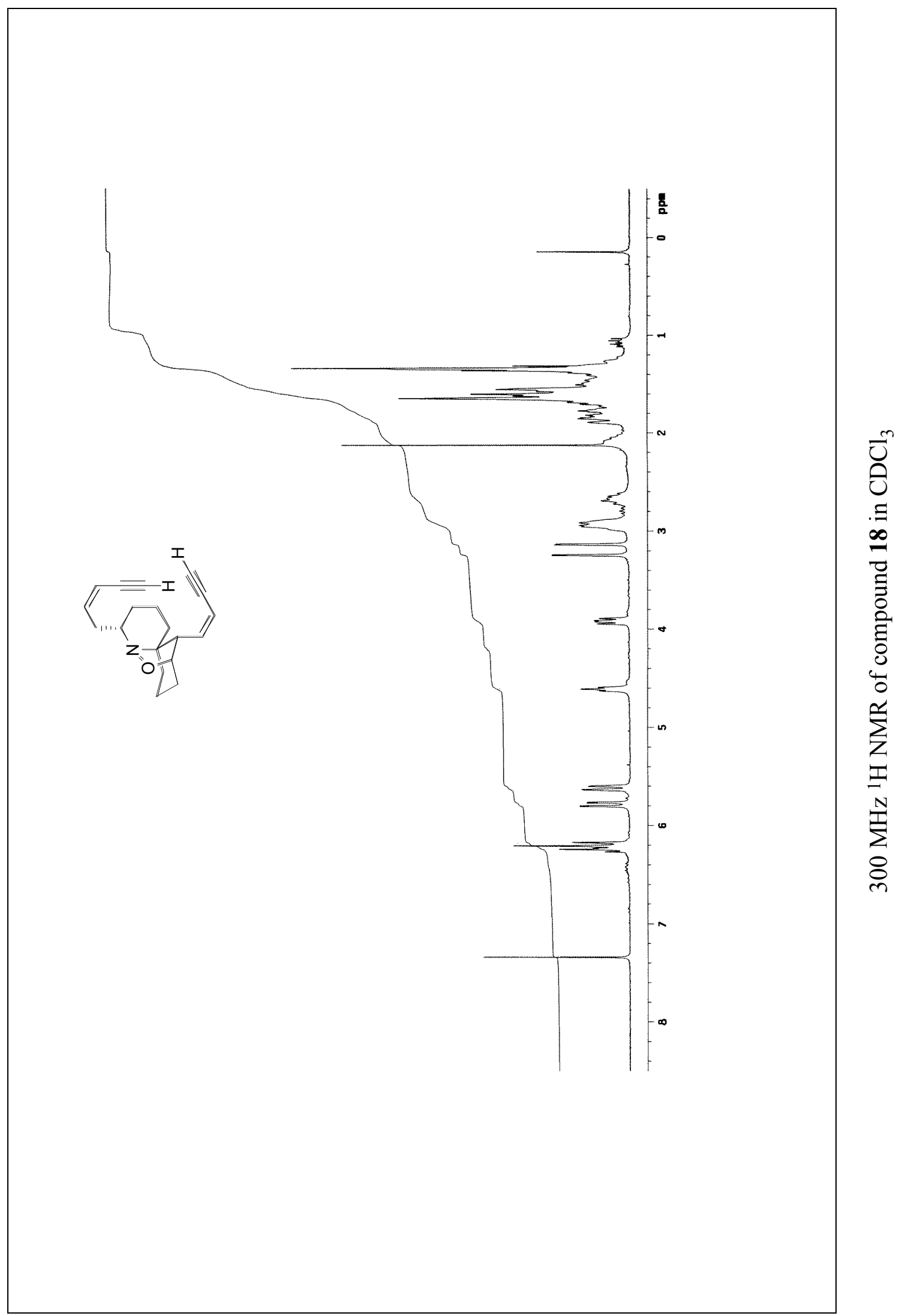




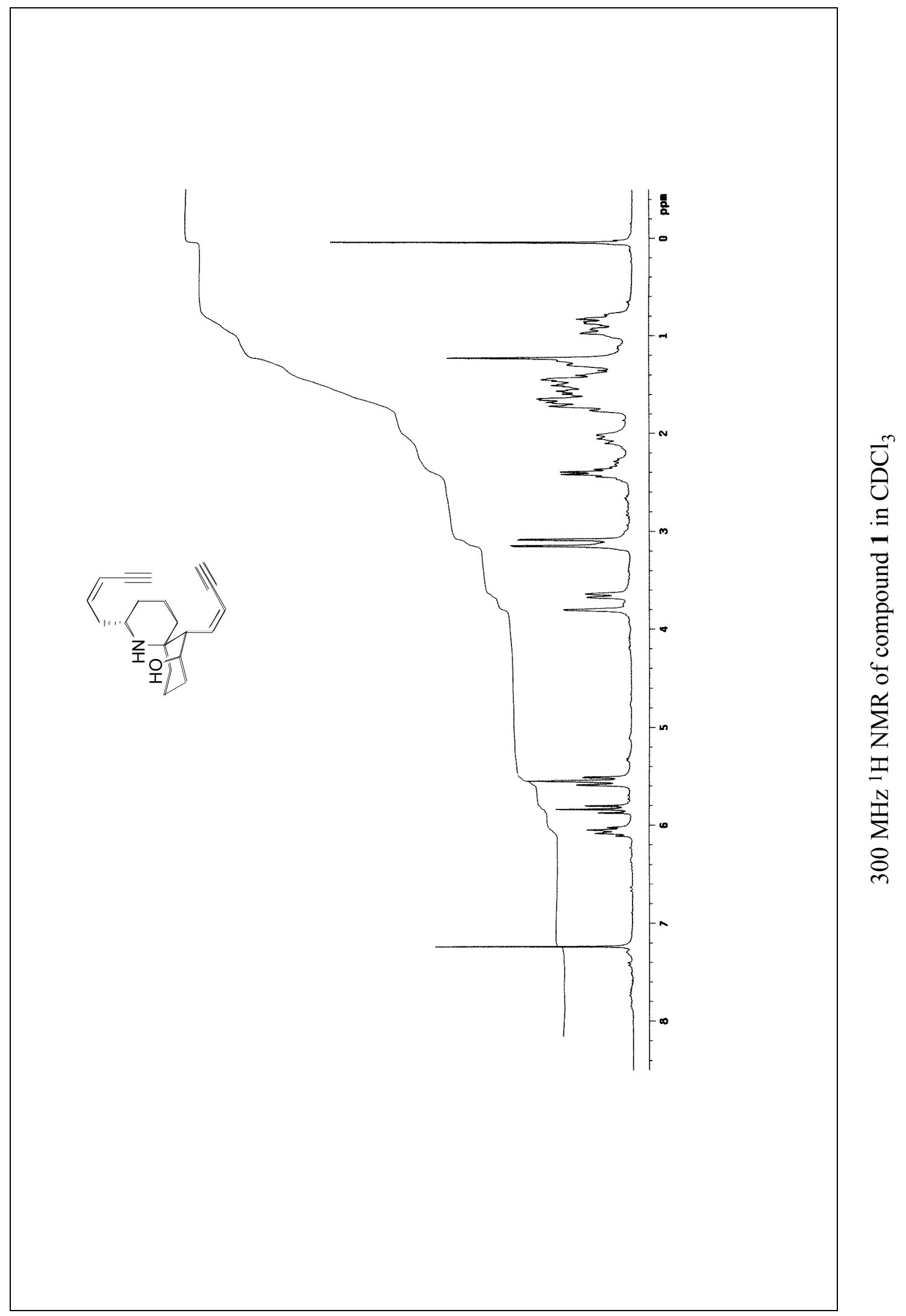




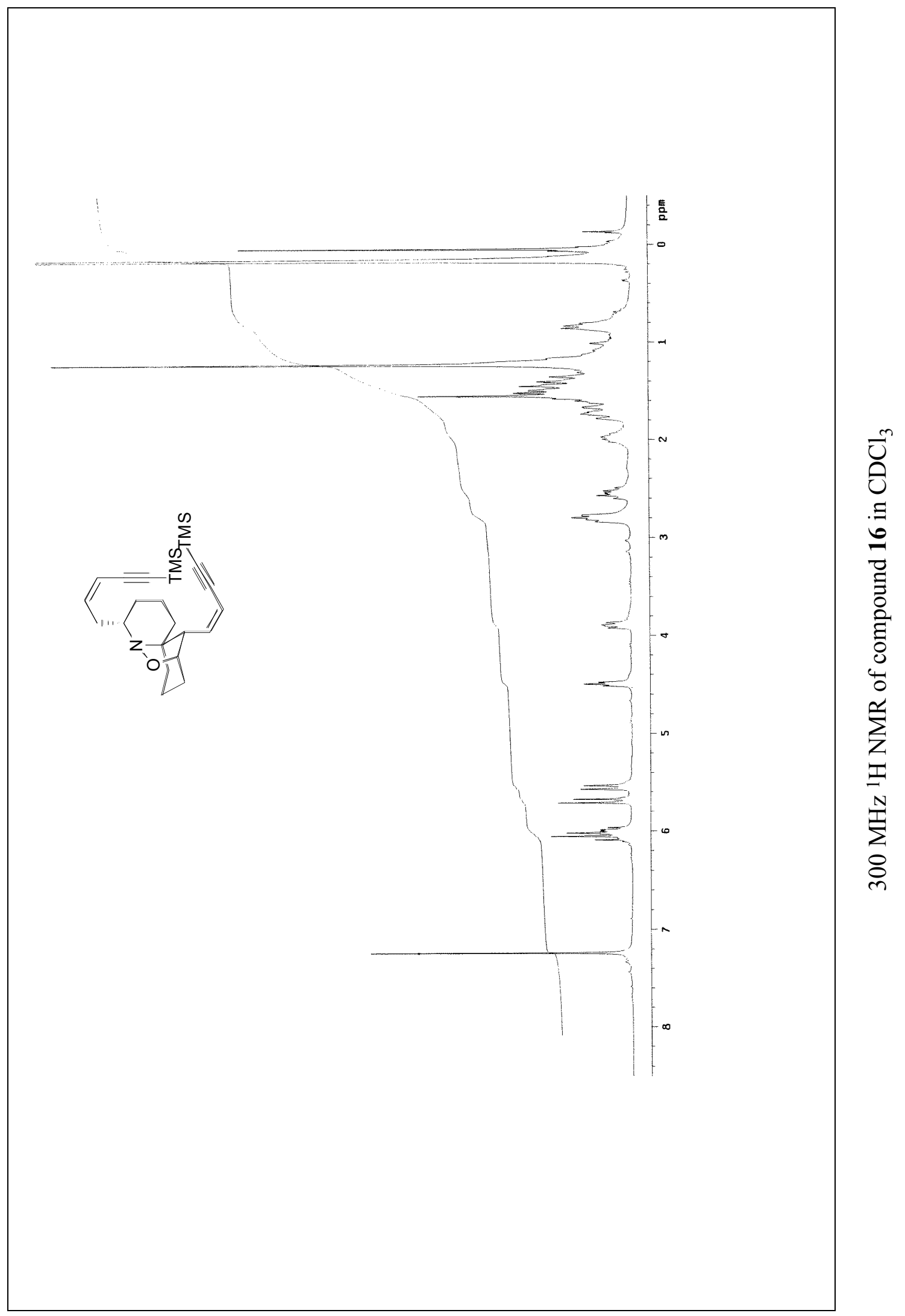




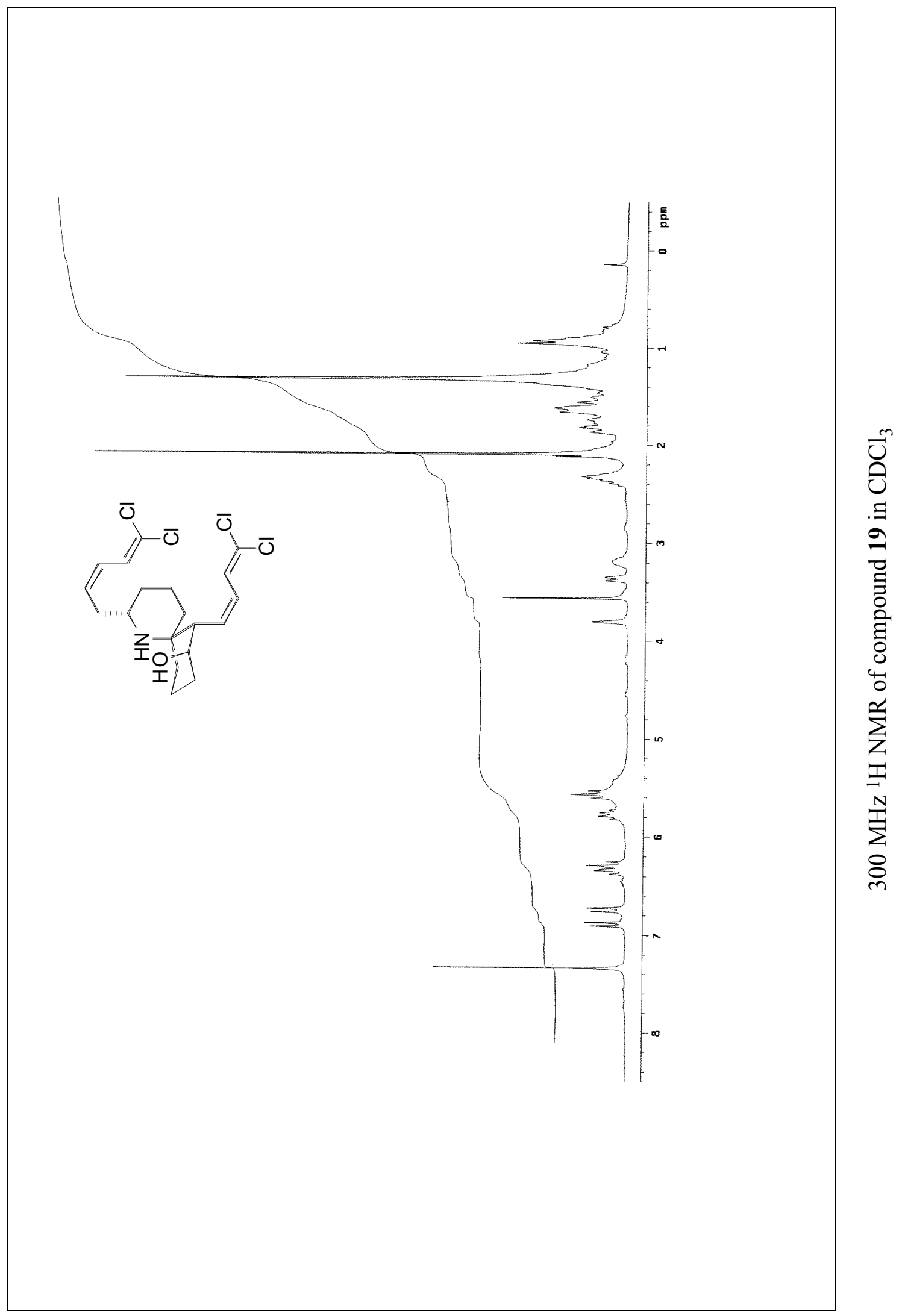




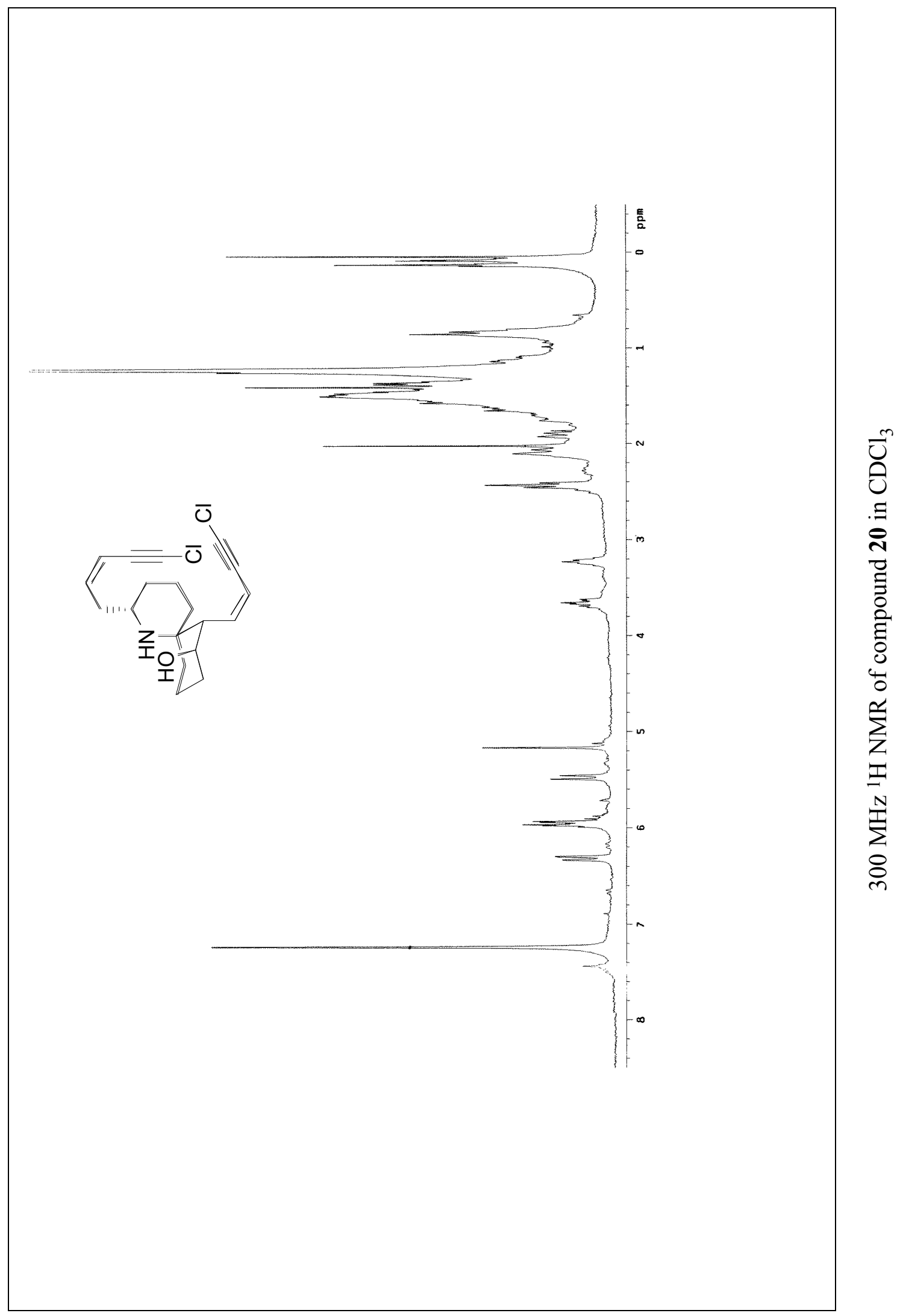




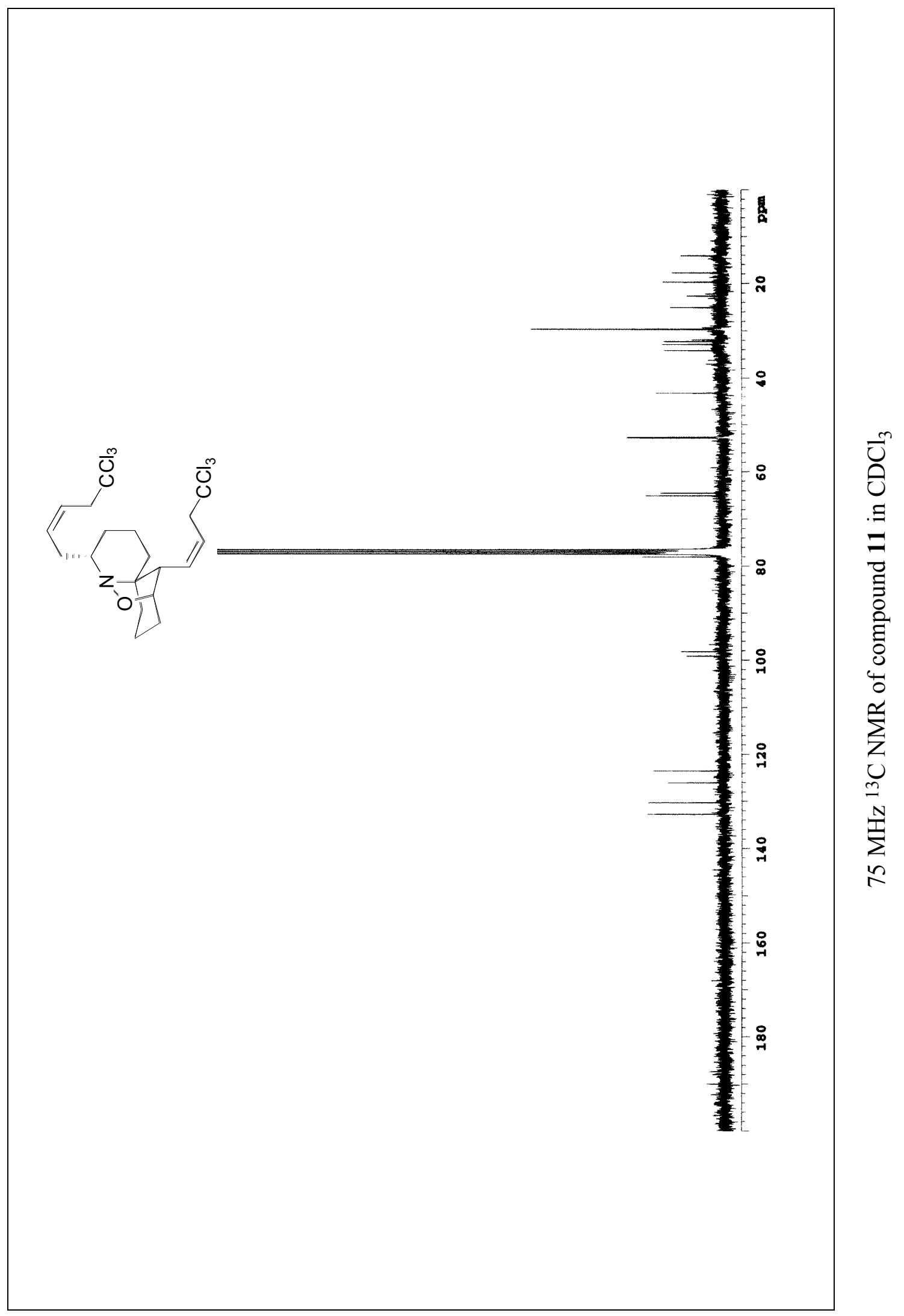




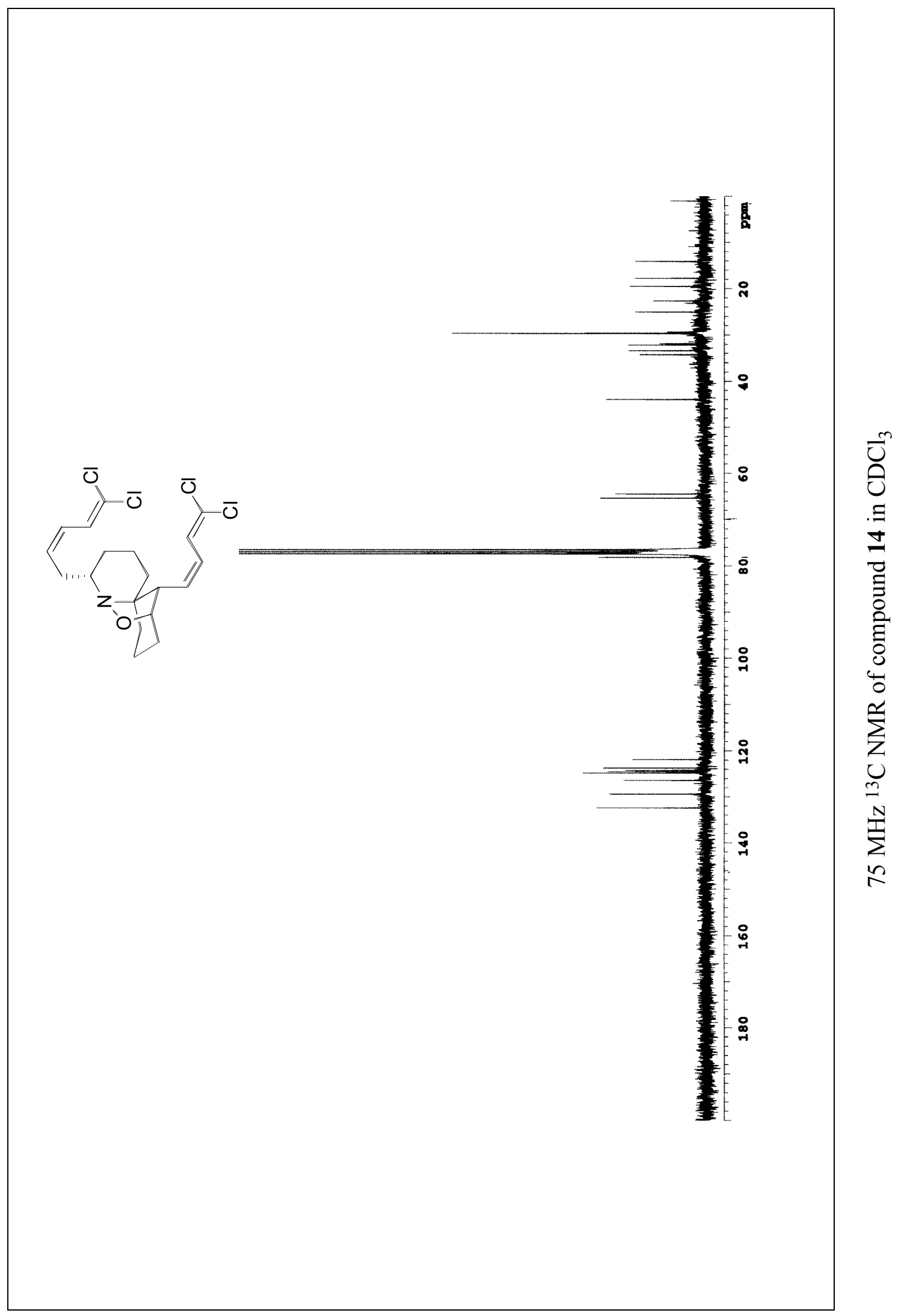




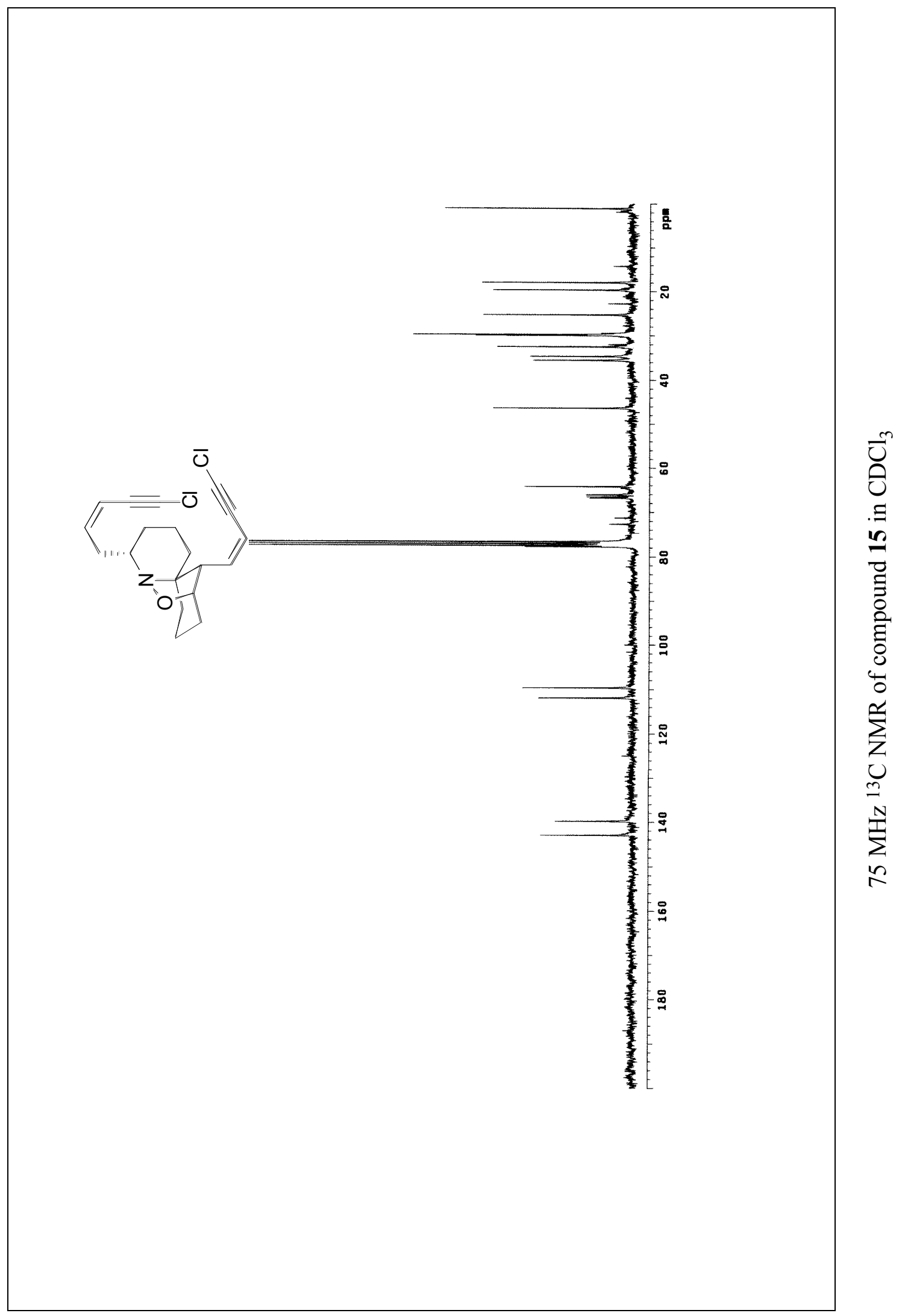




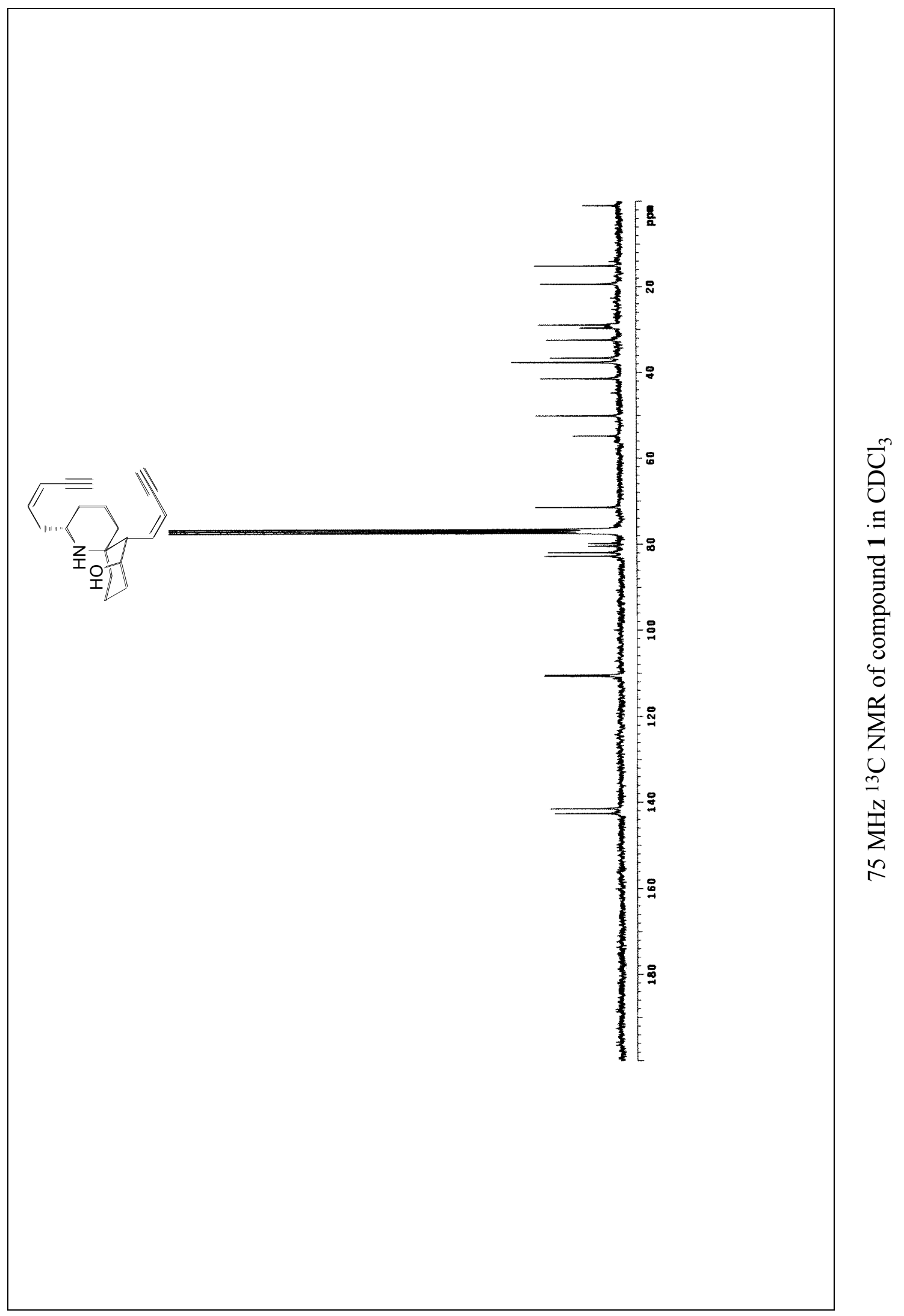

